\title{
Long-Term and Seasonal Changes in Nutrients, Phytoplankton Biomass, and Dissolved Oxygen in Deep Bay, Hong Kong
}

\author{
Jie Xu • Kedong Yin • Joseph H. W. Lee • Hongbin Liu • \\ Alvin Y. T. Ho • Xiangcheng Yuan • Paul J. Harrison
}

Received: 29 September 2008 /Revised: 10 July 2009 / Accepted: 26 July 2009 / Published online: 26 September 2009

(C) Coastal and Estuarine Research Federation 2009

\begin{abstract}
Deep Bay is a semienclosed bay that receives sewage from Shenzhen, a fast-growing city in China. $\mathrm{NH}_{4}$ is the main $\mathrm{N}$ component of the sewage $(>50 \%$ of total $\mathrm{N}$ ) in the inner bay, and a twofold increase in $\mathrm{NH}_{4}$ and $\mathrm{PO}_{4}$ concentrations is attributed to increased sewage loading over the 21-year period (1986-2006). During this time series, the maximum annual average $\mathrm{NH}_{4}$ and $\mathrm{PO}_{4}$ concentrations exceeded 500 and $39 \mu \mathrm{M}$, respectively. The inner bay (Stns DM1 and DM2) has a long residence time and very high nutrient loads and yet much lower phytoplankton biomass (chlorophyll (Chl) $<10 \mu \mathrm{g} \mathrm{L} \mathrm{L}^{-1}$ except for Jan, July, and Aug) and few severe long-term hypoxic events (dissolved oxygen (DO) generally $\left.>2 \mathrm{mg} \mathrm{L}^{-1}\right)$ than expected. Because it is shallow $(\sim 2 \mathrm{~m})$,
\end{abstract}

J. Xu $(\bowtie) \cdot$ H. Liu $\cdot$ A. Y. T. Ho $\cdot$ X. Yuan • P. J. Harrison

Atmospheric, Marine, and Coastal Environment (AMCE)

Program, The Hong Kong University of Science and Technology,

Clear Water Bay, Kowloon,

Hong Kong SAR, People's Republic of China

e-mail: xujie@ust.hk

\section{K. Yin}

Australian Rivers Institute, Griffith University,

Nathan Campus,

Brisbane, Queensland 4111, Australia

\section{J. H. W. Lee}

Department of Civil Engineering, The University of Hong Kong, Pokfulam Road,

Hong Kong SAR, People's Republic of China

K. Yin

Key Laboratory of Tropical Marine Environmental Dynamics,

South China Sea Institute of Oceanology,

Chinese Academy of Sciences,

Guangzhou, China phytoplankton growth is likely limited by light due to mixing and suspended sediments, as well as by ammonium toxicity, and biomass accumulation is reduced by grazing, which may reduce the occurrence of hypoxia. Since nutrients were not limiting in the inner bay, the significant long-term increase in Chl $a\left(0.52-0.57 \mu \mathrm{g} \mathrm{L}^{-1}\right.$ year $\left.^{-1}\right)$ was attributed to climatic effects in which the significant increase in rainfall $\left(11 \mathrm{~mm}\right.$ year $\left.^{-1}\right)$ decreased salinity, increased stratification, and improved water stability. The outer bay (DM3 to DM5) has a high flushing rate $\left(0.2\right.$ day $\left.^{-1}\right)$, is deeper ( 3 to $\left.5 \mathrm{~m}\right)$, and has summer stratification, yet there are few large algal blooms and hypoxic events since dilution by the Pearl River discharge in summer, and the invasion of coastal water in winter is likely greater than the phytoplankton growth rate. A significant long-term increase in $\mathrm{NO}_{3}\left(0.45-0.94 \mu \mathrm{M}\right.$ year $\left.{ }^{-1}\right)$ occurred in the outer bay, but no increasing trend was observed for $\mathrm{SiO}_{4}$ or $\mathrm{PO}_{4}$, and these long-term trends in $\mathrm{NO}_{3}, \mathrm{PO}_{4}$, and $\mathrm{SiO}_{4}$ in the outer bay agreed with those long-term trends in the Pearl River discharge. Dissolved inorganic nitrogen (DIN) has approximately doubled from 35-62 to 68$107 \mu \mathrm{M}$ in the outer bay during the last two decades, and consequently DIN to $\mathrm{PO}_{4}$ molar ratios have also increased over twofold since there was no change in $\mathrm{PO}_{4}$. The rapid increase in salinity and DO and the decrease in nutrients and suspended solids from the inner to the outer bay suggest that the sewage effluent from the inner bay is rapidly diluted and appears to have a limited effect on the phytoplankton of the adjacent waters beyond Deep Bay. Therefore, physical processes play a key role in reducing the risk of algal blooms and hypoxic events in Deep Bay.

Keywords Eutrophication - Nutrients . Phytoplankton biomass · Dissolved oxygen · Sewage · Hong Kong · Deep Bay 


\section{Introduction}

Eutrophication has been considered to be a major threat to marine ecosystems for several decades (Ryther and Dunstan 1971; Rosenberg 1985; Nixon 1995; Bachmann et al. 2006) since nutrient enrichment can disrupt biological communities and ecosystem processes in the coastal areas (Cloern 1999). In weakly flushed waters, the increased loading of $\mathrm{N}$ and $\mathrm{P}$ increases phytoplankton biomass and oxygen demand due to the decomposition of more organic matter, leading to hypoxia or anoxia in some cases (Cooper and Brush 1991; Boynton et al. 1995; Malakoff 1998; Fisher et al. 2006). In contrast, increased nutrient loading has less effect in turbid waters (Cloern 1999, 2001; Le Pape et al. 1996) where phytoplankton growth is often light-limited all year (Heip et al. 1995), or algal biomass is diluted due to high mixing and flushing rates (Ball et al. 1995).

Climatic change also affects ecological responses to coastal eutrophication (Howarth et al. 2000). Freshwater inputs can increase nutrient loads and stratification of the water column and lead to an increase in phytoplankton biomass and a subsequent potential depletion of bottom dissolved oxygen (DO; Justić et al. 1997). On the other hand, increased freshwater discharge could decrease phytoplankton growth due to light limitation caused by an increase in the load of the suspended solids (SS) and reduce residence time of the embayment, leading to low phytoplankton biomass (Le Pape et al. 1996; Howarth et al. 2000).

A number of water quality monitoring programs have been established to analyze long-term trends and changes in water quality in many regions of the world. Long-term measurements provide evidence for the evolution of eutrophication impacts and the ecosystem response to changes in nutrient supply in coastal areas (e.g., O'Shea and Brosnan 2000; Gowen et al. 2002; Paerl et al. 2006).

In Hong Kong waters, anthropogenic nutrient loads are from seasonally varying inputs from the Pearl River and year-round inputs from Hong Kong sewage. Presently, there is little information on whether the high nutrient
Fig. 1 Location of the sampling stations in Hong Kong waters. These five stations are the same as the EPD monitoring stations. The number in the bracket represents the water depth

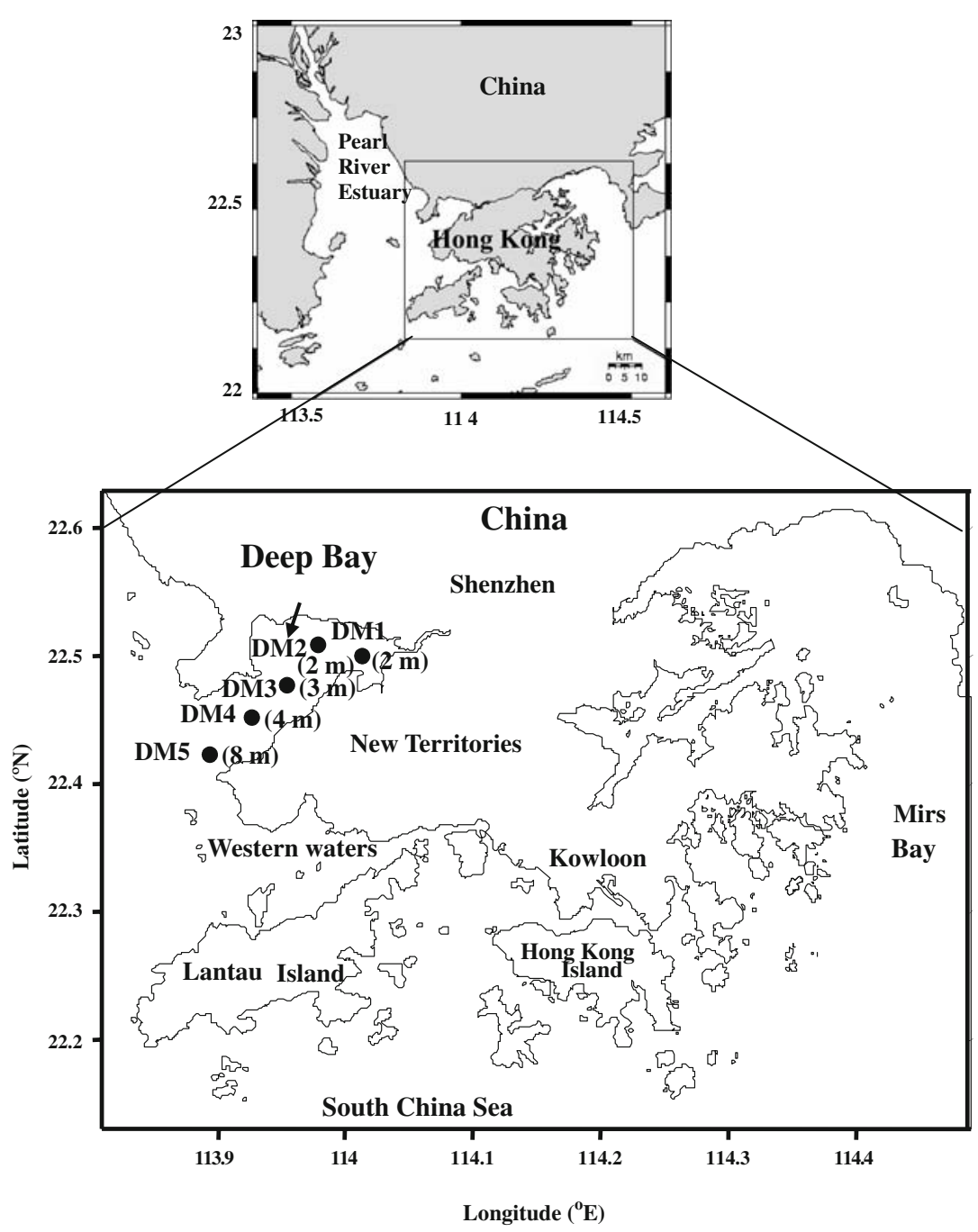


concentrations $\left(\mathrm{NH}_{4}>400 \mu \mathrm{M}\right)$ from sewage inputs into Deep Bay also influence Hong Kong waters.

Deep Bay is a shallow semienclosed bay which is surrounded by a large megacity, Shenzhen, to the north and the New Territories of Hong Kong to the south (Fig. 1). It is influenced by four rivers with very small discharges. The entrance of the bay is located to the southwest where it joins the Pearl River estuary. Deep Bay has suffered from extensive anthropogenic pollutant inputs such as unsewered villages and livestock farms (Environmental Protection Department (EPD) 2004). The results of a recent evaluation indicated that the water quality of Deep Bay was the worst among all the waters of Hong Kong in terms of nutrient concentrations (EPD 2006), with threats to sensitive ecosystems (wetland reserves) and oyster culturing in the bay (Lee and Qian 2003). However, little is known about the long-term response of this ecosystem to nutrient enrichment in Deep Bay in terms of phytoplankton biomass and DO in the bottom water. The objective of this paper was to evaluate the 21-year long-term trends and seasonal variations in nutrients, phytoplankton biomass, and DO in Deep Bay due to a twofold increase in nutrient loading. This is the first comprehensive analysis of water quality parameters for Deep Bay. From this time series analysis, we were also able to determine that the high nutrient loading in the inner bay is diluted by the Pearl River as the water exits the bay, and therefore this nutrient load from Deep Bay has little influence on the immediate surrounding Hong Kong waters.

\section{Materials and Methods}

The EPD of the Hong Kong government has maintained a comprehensive sampling program to monitor water quality at $>76$ monitoring stations in the territorial waters since the late 1980s (website: www.epd.gov.hk). Five stations located in the Deep Bay were grouped into two sections: the inner bay (DM1 and DM2) and the outer bay (DM3, DM4, and DM5; Fig. 1). Bimonthly sampling in 1986 and 1987 and monthly sampling since 1988 were conducted by EPD during the 21-year time series in Deep Bay, except for DM5 where monthly sampling was conducted from 1991 to 2006. The dry season was defined as October to March, and the wet season was from April to September. The year was divided into four seasons: spring (March to May), summer (June to August), fall (September to November), and winter (December to February). Water samples were taken only at the surface ( $1 \mathrm{~m}$ below the surface) at DM1, DM2, and
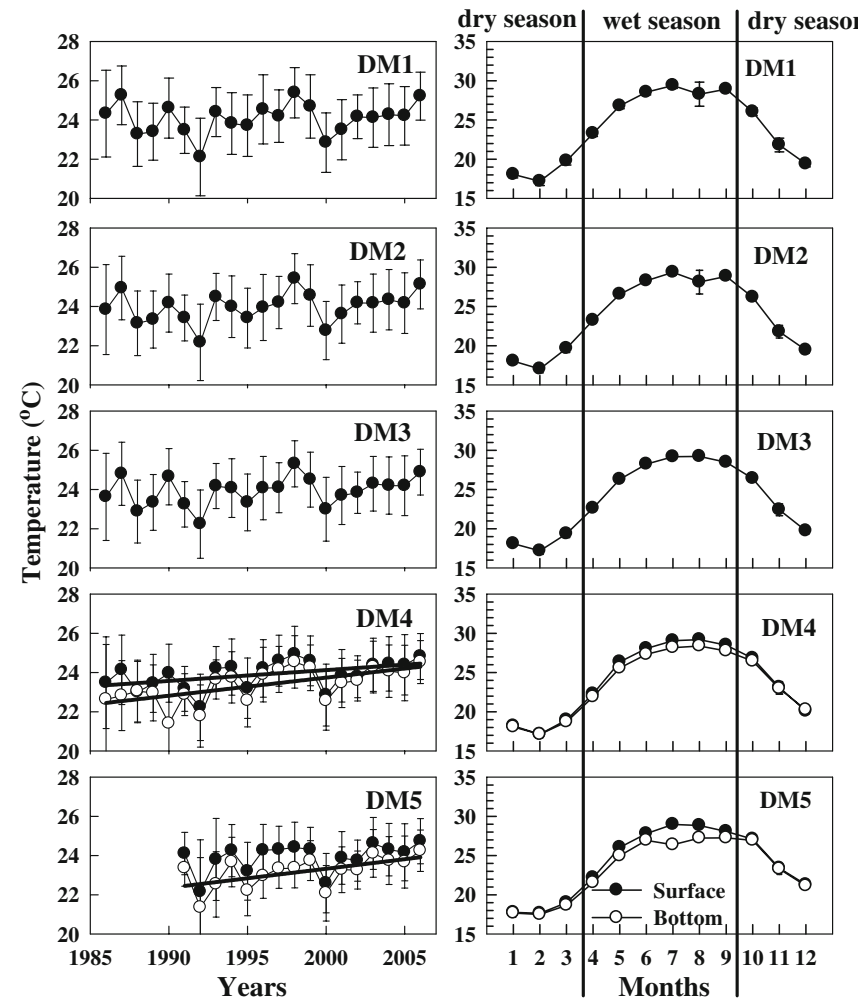

Fig. 2 Annual average temperature and salinity and monthly average temperature and salinity at the surface (DM1, DM2, and DM3) and surface and bottom (DM4 and DM5) at five stations in Deep Bay during 1986-2006. The line represents a significant linear regression
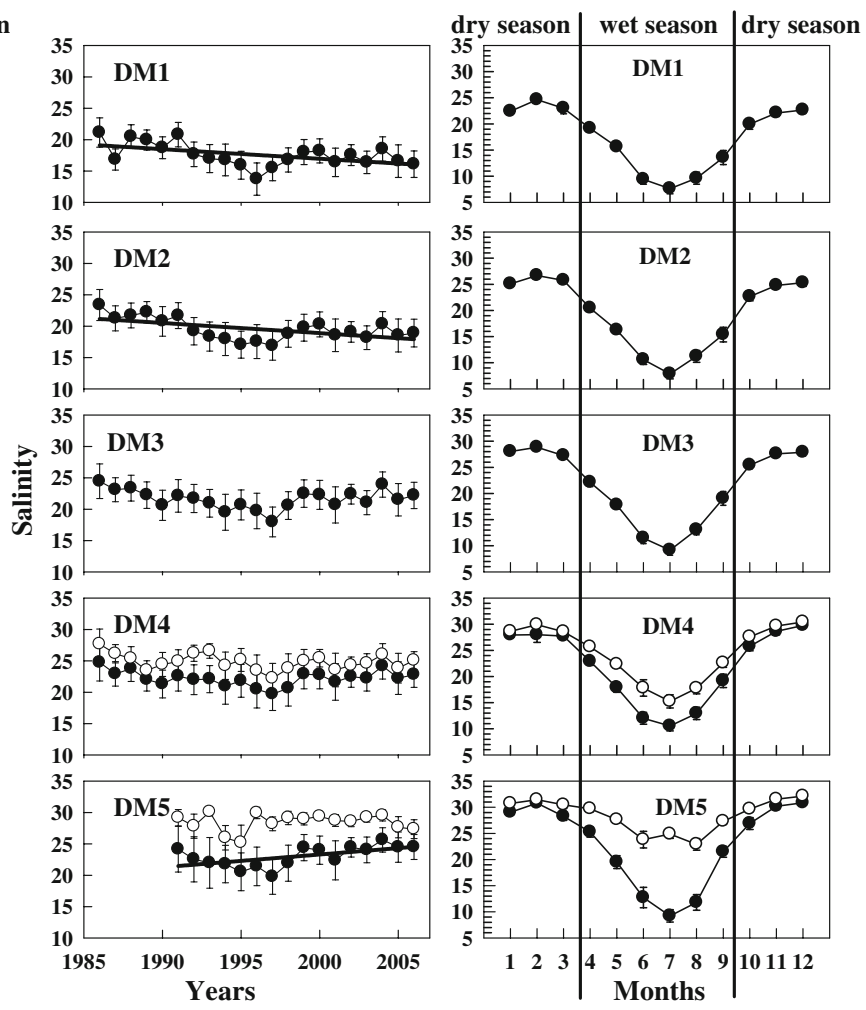

trend $(p<0.05)$. Vertical bars indicate \pm 1 SE and $n=6$ during 1986 1987 and $n=12$ during 1988-2006 at all stations for the annual average data and $n=21$ for DM1 to DM4 and $n=16$ for DM5 for the monthly average data 
Table 1 Long-term trends in 15 variables in Deep Bay during 1986-2006

\begin{tabular}{|c|c|c|c|c|c|c|c|c|c|c|c|}
\hline Stations & Layer & Variables & Slope & $r^{2}$ & Number & Stations & Layer & Variables & Slope & $r^{2}$ & Number \\
\hline \multirow[t]{2}{*}{ DM4 } & $\mathrm{S}$ & \multirow[t]{3}{*}{ Temp } & 0.06 & 0.23 & 21 & DM1 & \multirow[t]{3}{*}{$\mathrm{S}$} & \multirow[t]{3}{*}{ Salinity } & -0.15 & 0.26 & 21 \\
\hline & B & & 0.09 & 0.43 & 21 & DM2 & & & -0.16 & 0.32 & 21 \\
\hline DM5 & $\mathrm{S}$ & & 0.10 & 0.35 & 16 & DM5 & & & 0.2 & 0.34 & 16 \\
\hline DM1 & $\mathrm{S}$ & \multirow[t]{6}{*}{$\mathrm{NH}_{4}$} & 8.2 & 0.26 & 21 & DM2 & $\mathrm{S}$ & $\mathrm{TN}$ & 8.5 & 0.46 & 21 \\
\hline DM2 & & & 8.2 & 0.55 & 21 & DM4 & $\mathrm{S}$ & & 2.15 & 0.46 & 21 \\
\hline \multirow[t]{2}{*}{ DM4 } & $\mathrm{S}$ & & 1.3 & 0.73 & 21 & & B & & 1.83 & 0.37 & 21 \\
\hline & B & & 1.1 & 0.68 & 21 & DM1 & $\mathrm{S}$ & $\mathrm{PO}_{4}$ & -0.56 & 0.25 & 21 \\
\hline \multirow[t]{2}{*}{ DM5 } & $\mathrm{S}$ & & 1.07 & 0.81 & 16 & DM1 & $\mathrm{S}$ & $\mathrm{TP}$ & -1.76 & 0.21 & 21 \\
\hline & $\mathrm{B}$ & & 0.67 & 0.71 & 16 & DM5 & $\mathrm{S}$ & & -0.12 & 0.75 & 16 \\
\hline DM3 & $\mathrm{S}$ & \multirow[t]{5}{*}{$\mathrm{NO}_{2}$} & 0.37 & 0.37 & 21 & & B & & -0.13 & 0.64 & 16 \\
\hline \multirow[t]{2}{*}{ DM4 } & $\mathrm{S}$ & & 0.38 & 0.44 & 21 & DM1 & \multirow[t]{2}{*}{$\mathrm{S}$} & \multirow[t]{2}{*}{$\mathrm{DIN}$ to $\mathrm{PO}_{4}$} & 0.84 & 0.36 & 21 \\
\hline & $\mathrm{B}$ & & 0.39 & 0.74 & 21 & DM2 & & & 0.82 & 0.51 & 21 \\
\hline \multirow[t]{2}{*}{ DM5 } & $\mathrm{S}$ & & 0.47 & 0.74 & 16 & DM4 & $\mathrm{S}$ & DIN to $\mathrm{SiO}_{4}$ & 0.07 & 0.61 & 21 \\
\hline & $\mathrm{B}$ & & 0.3 & 0.68 & 16 & & $\mathrm{~B}$ & & 0.06 & 0.66 & 21 \\
\hline DM2 & $\mathrm{S}$ & \multirow[t]{4}{*}{$\mathrm{NO}_{3}$} & 0.77 & 0.43 & 21 & DM5 & $\mathrm{S}$ & & 0.06 & 0.55 & 16 \\
\hline \multirow[t]{2}{*}{ DM4 } & $\mathrm{S}$ & & 0.91 & 0.41 & 21 & & $\mathrm{~B}$ & & 0.05 & 0.69 & 16 \\
\hline & $\mathrm{B}$ & & 0.94 & 0.67 & 21 & DM1 & \multirow[t]{2}{*}{$\mathrm{S}$} & \multirow[t]{2}{*}{ Chl $a$} & 0.57 & 0.19 & 21 \\
\hline DM5 & $\mathrm{S}$ & & 0.45 & 0.30 & 16 & DM2 & & & 0.52 & 0.21 & 21 \\
\hline DM1 & $\mathrm{S}$ & DIN & 7.4 & 0.28 & 21 & DM3 & $\mathrm{S}$ & SS & 0.71 & 0.32 & 21 \\
\hline DM2 & & & 8.3 & 0.63 & 21 & DM1 & S & DO & -0.08 & 0.3 & 21 \\
\hline DM3 & & & 2.6 & 0.41 & 21 & $\mathrm{DM} 2$ & & & -0.09 & 0.39 & 21 \\
\hline \multirow[t]{2}{*}{ DM4 } & $\mathrm{S}$ & & 2.6 & 0.75 & 21 & DM3 & & & -0.07 & 0.31 & 21 \\
\hline & B & & 2.4 & 0.83 & 21 & DM4 & & & -0.08 & 0.63 & 21 \\
\hline \multirow[t]{2}{*}{ DM5 } & $\mathrm{S}$ & & 1.98 & 0.84 & 16 & DM5 & S & & -0.13 & 0.61 & 16 \\
\hline & $\mathrm{B}$ & & 1.3 & 0.57 & 16 & & B & & -0.07 & 0.48 & 16 \\
\hline DM1 & & SDD & -0.03 & 0.48 & 9 & DM2 & $\mathrm{S}$ & BOD & 0.11 & 0.52 & 21 \\
\hline DM4 & & & -0.07 & 0.53 & 9 & & & & & & \\
\hline
\end{tabular}

Trend evaluated by a linear regression at a significance level of $p<0.05$. Minus sign denotes a significant decreasing trend $S$ surface, $B$ bottom layer

DM3, due to their shallow depth, and were assumed to be representative of the whole water column, especially in reference to DO. In contrast, water samples were taken at three depths: surface ( $1 \mathrm{~m}$ below the surface), middle (data

Table 2 Long-term trends analyzed by a linear regression for summer and winter temperatures in outer Deep Bay during 1986-2006

\begin{tabular}{llllll}
\hline Stations & Layer & Seasons & Slope & $r^{2}$ & Number \\
\hline DM3 & S & Summer & 0.08 & 0.19 & 21 \\
DM4 & S & Summer & 0.08 & 0.26 & 21 \\
& & Winter & 0.08 & 0.20 & 21 \\
& B & Summer & 0.09 & 0.28 & 21 \\
& & Winter & 0.09 & 0.22 & 21 \\
DM5 & S & Summer & 0.14 & 0.53 & 16 \\
& B & Winter & 0.23 & 0.27 & 16 \\
\hline
\end{tabular}

$S$ surface, $B$ bottom layer not shown), and bottom (1 $\mathrm{m}$ above the bottom) at the deep stations (DM4 and DM5). Methods for sampling and routine water quality measurements are reported by EPD (EPD 2006), and the methods during the 21-year time series were standard methods for the examination of water and wastewater by the American Public Health Association and Annual Book of American Society for the Testing and Materials standards for nutrients, DO, biological oxygen demand, SS, and chlorophyll (Chl). Chlorophyll was extracted with $90 \%$ acetone and measured using a spectrophotometer at 664,647 , and $630 \mathrm{~nm}$. The optical density at $750 \mathrm{~nm}$ is a correction for turbidity. Chl $a$ concentrations were calculated according to the equations proposed by Jeffrey and Humphrey (1975).

\section{Statistical Analyses}

Linear regressions were used to analyze the time series using Sigmaplot $9.0(n=$ number of sampling months in a year for 
Table $3 \mathrm{pH}$ values at the surface in Deep Bay during 1986-2006
Error bar represents $\pm 1 \mathrm{SE}, n=$ 21 for DM1, DM2, DM3, and DM4 and $n=16$ for DM5

\begin{tabular}{clllll}
\hline Month & DM1 & DM2 & DM3 & DM4 & DM5 \\
\hline 1 & $7.61 \pm 0.12$ & $7.79 \pm 0.10$ & $8.03 \pm 0.07$ & $8.06 \pm 0.06$ & $8.10 \pm 0.06$ \\
2 & $7.53 \pm 0.07$ & $7.66 \pm 0.07$ & $7.88 \pm 0.06$ & $8.04 \pm 0.04$ & $8.05 \pm 0.06$ \\
3 & $7.48 \pm 0.06$ & $7.68 \pm 0.08$ & $7.78 \pm 0.09$ & $7.99 \pm 0.05$ & $8.01 \pm 0.05$ \\
4 & $7.55 \pm 0.08$ & $7.66 \pm 0.06$ & $7.83 \pm 0.08$ & $7.92 \pm 0.08$ & $7.94 \pm 0.08$ \\
5 & $7.47 \pm 0.07$ & $7.60 \pm 0.08$ & $7.77 \pm 0.11$ & $7.93 \pm 0.07$ & $7.88 \pm 0.12$ \\
6 & $7.46 \pm 0.09$ & $7.59 \pm 0.08$ & $7.93 \pm 0.09$ & $7.96 \pm 0.06$ & $7.83 \pm 0.07$ \\
7 & $7.37 \pm 0.14$ & $7.49 \pm 0.14$ & $7.74 \pm 0.13$ & $7.91 \pm 0.13$ & $7.91 \pm 0.14$ \\
8 & $7.68 \pm 0.09$ & $7.68 \pm 0.09$ & $7.87 \pm 0.10$ & $7.98 \pm 0.07$ & $7.89 \pm 0.08$ \\
9 & $7.53 \pm 0.10$ & $7.59 \pm 0.11$ & $7.82 \pm 0.08$ & $7.90 \pm 0.08$ & $7.80 \pm 0.09$ \\
10 & $7.48 \pm 0.12$ & $7.64 \pm 0.10$ & $7.91 \pm 0.08$ & $8.02 \pm 0.05$ & $7.98 \pm 0.06$ \\
11 & $7.10 \pm 0.40$ & $7.26 \pm 0.41$ & $7.84 \pm 0.08$ & $7.98 \pm 0.06$ & $8.03 \pm 0.04$ \\
12 & $7.52 \pm 0.07$ & $7.62 \pm 0.07$ & $7.76 \pm 0.09$ & $7.97 \pm 0.06$ & $8.01 \pm 0.08$ \\
\hline
\end{tabular}

the annual average data and number of sampling years for the monthly average data). Correlations of $\mathrm{NH}_{4}$ vs salinity and DO vs temperature were analyzed by the SPSS Program (Pearson test). A $t$ test analysis was conducted to determine any significant difference between variables $(p<0.05)$.

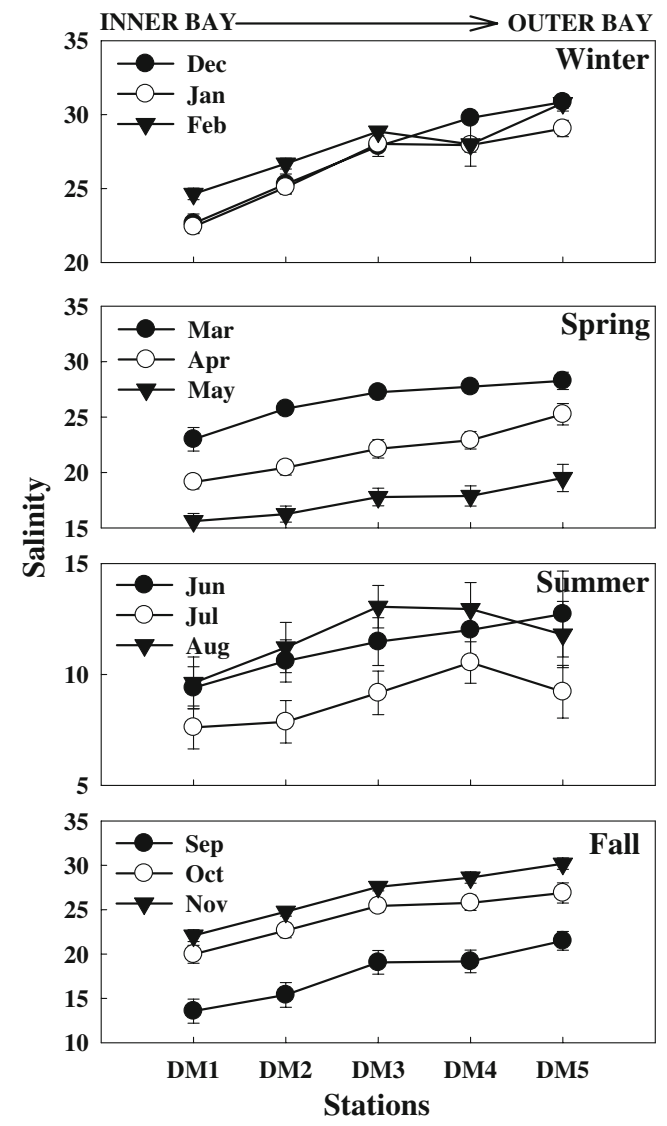

Fig. 3 Monthly average salinity at the surface along the transect from the inner bay to outer bay in four seasons during 1986-2006. Vertical bars indicate $\pm 1 \mathrm{SE}$ and $n=21$ for DM1 to DM4 and $n=16$ for DM5. Note the change in the scale on the $y$-axis

\section{Results}

Temperature, Salinity, and $\mathrm{pH}$

Annual average surface temperature exhibited no significant trends at DM1, DM2, and DM3 but rose significantly at the surface and bottom at DM4 and at the surface at DM5 at the rate of $0.06-0.1^{\circ} \mathrm{C}_{\text {year }}{ }^{-1}$ (Fig. 2, Table 1). In summer, there was a long-term increase in temperature at the surface at DM3 and at the surface and bottom at DM4 by $0.08-0.09^{\circ} \mathrm{C}_{\text {year }}{ }^{-1}$. In winter, temperature increased at the surface and bottom at DM4 and at the bottom at DM5 at the rate of $0.08-0.23^{\circ} \mathrm{C} \mathrm{y}^{-1}$ (Table 2). Surface temperature fluctuated from a low of $17-21^{\circ} \mathrm{C}$ in winter to a high of $28-30^{\circ} \mathrm{C}$ in summer (Fig. 2). The pH value increased from 7.1-7.8 in the inner bay to 7.8-8.1 in the outer bay (Table 3).

Annual average surface salinity decreased significantly by 0.15 year $^{-1}$ at DM1 and 0.16 year $^{-1}$ at DM2 and increased by 0.2 year $^{-1}$ at the surface of DM5 (Fig. 2, Table 1). Surface salinity fluctuated seasonally with high salinity $(22-31)$ in the winter and low salinity $(7.5-13)$ in the summer at all stations (Fig. 2). Surface salinity increased along the transect from DM1 to DM5 during March to June and September to December. In July, the highest surface salinity occurred at DM4 (10.5), significantly ( $p<0.05, t$ test) higher than that at DM5 (9.2) due to dilution by the Pearl River discharge at DM5 (Fig. 3).

Nutrients and Nutrient Ratios

Annual average $\mathrm{NH}_{4}$ concentrations exhibited a significant increase in the water column in the inner bay (DM1 and DM2) by $8.2 \mu \mathrm{M}$ year $^{-1}$ and at the surface and bottom in the outer bay (DM4 and DM5) at the rate of 0.67 to $1.3 \mu \mathrm{M}$ year ${ }^{-1}$ (Fig. 4, Table 1). Seasonal patterns of $\mathrm{NH}_{4}$ were observed with high concentrations (up to $400 \mu \mathrm{M}$ at 

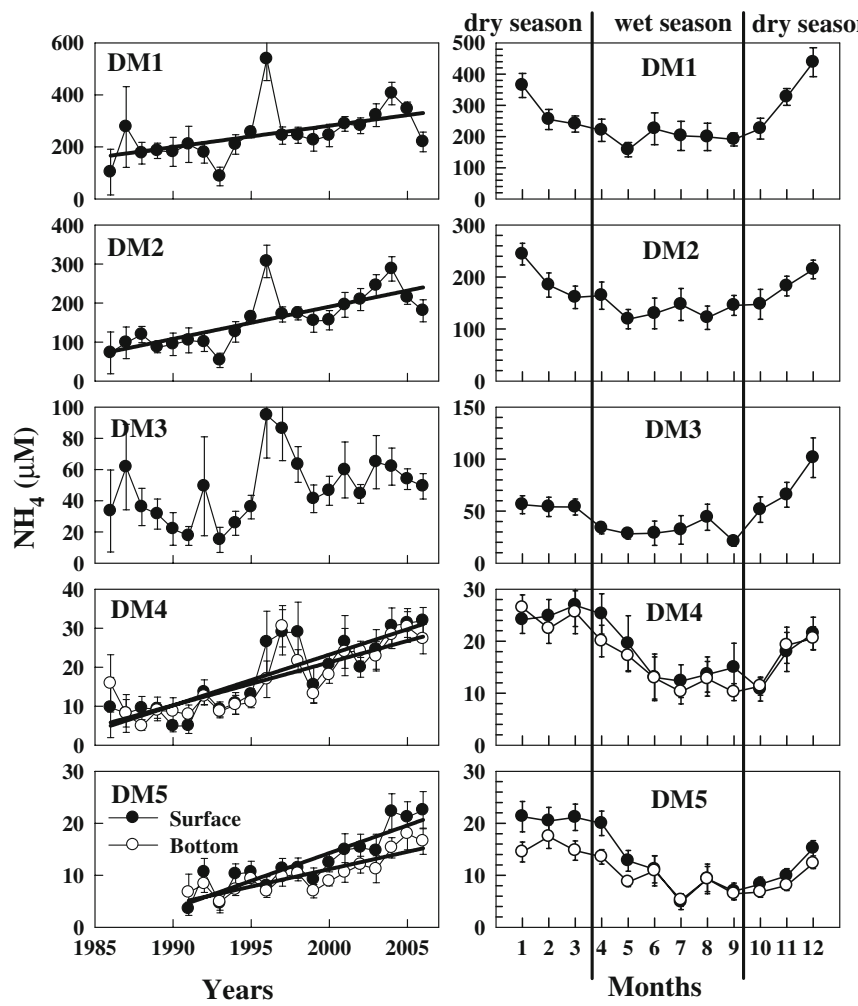

Fig. 4 Annual and monthly average $\mathrm{NH}_{4}$ and $\mathrm{NO}_{2}{ }^{-}$concentrations at the surface (DM1, DM2, and DM3) and surface and bottom (DM4 and DM5) at five stations in Deep Bay during 1986-2006. The linear regression line represents a significant trend $(p<0.05)$. Vertical bars

DM1) in the dry season and lower values in wet season throughout the bay. $\mathrm{NH}_{4}$ concentrations decreased markedly along the bay's axis. The monthly average $\mathrm{NH}_{4}$ values of 200 to $400 \mu \mathrm{M}$ at DM1 were one order of magnitude higher than the monthly average of $<25 \mu \mathrm{M}$ at DM5. Annual average $\mathrm{NO}_{2}{ }^{-}$concentrations doubled from $\sim 5$ to $>10 \mu \mathrm{M}$ during the 21-year period in the outer bay (DM3, DM4, and DM5; Fig. 4).

There was a significant $(p<0.05)$ long-term increase in $\mathrm{NO}_{3}$ at the surface at the rate of 0.45 to $0.94 \mu \mathrm{M}$ year ${ }^{-1}$ in the outer bay (DM3, DM4, and DM5) where strong seasonal variations in $\mathrm{NO}_{3}$ were observed at the surface, with high concentrations $(40$ to $80 \mu \mathrm{M})$ in the wet season and low values (10 to $40 \mu \mathrm{M})$ in the dry season (Fig. 5). Annual average DIN $\left(\mathrm{NH}_{4}+\mathrm{NO}_{2}{ }^{-}+\mathrm{NO}_{3}\right)$ concentrations increased significantly $(p<0.05)$ in the water column in the inner bay by 7.4 to $8.3 \mu \mathrm{M}$ year ${ }^{-1}$ and at the surface and bottom in the outer bay at the rate of 1.3 to $2.6 \mu \mathrm{M}$ year ${ }^{-1}$ and doubled from about 35 to $70 \mu \mathrm{M}$ in the water column throughout the bay during the last two decades. In contrast to the seasonality of $\mathrm{NH}_{4}$ and $\mathrm{NO}_{3}$, there were no obvious seasonal patterns for DIN and TN at DM2 and DM3, but DIN and TN were significantly $(p<0.05, t$ test) higher at DM1 in the dry season and at DM4 and DM5 in the wet season due to the invasion of Pearl River water at DM4 and
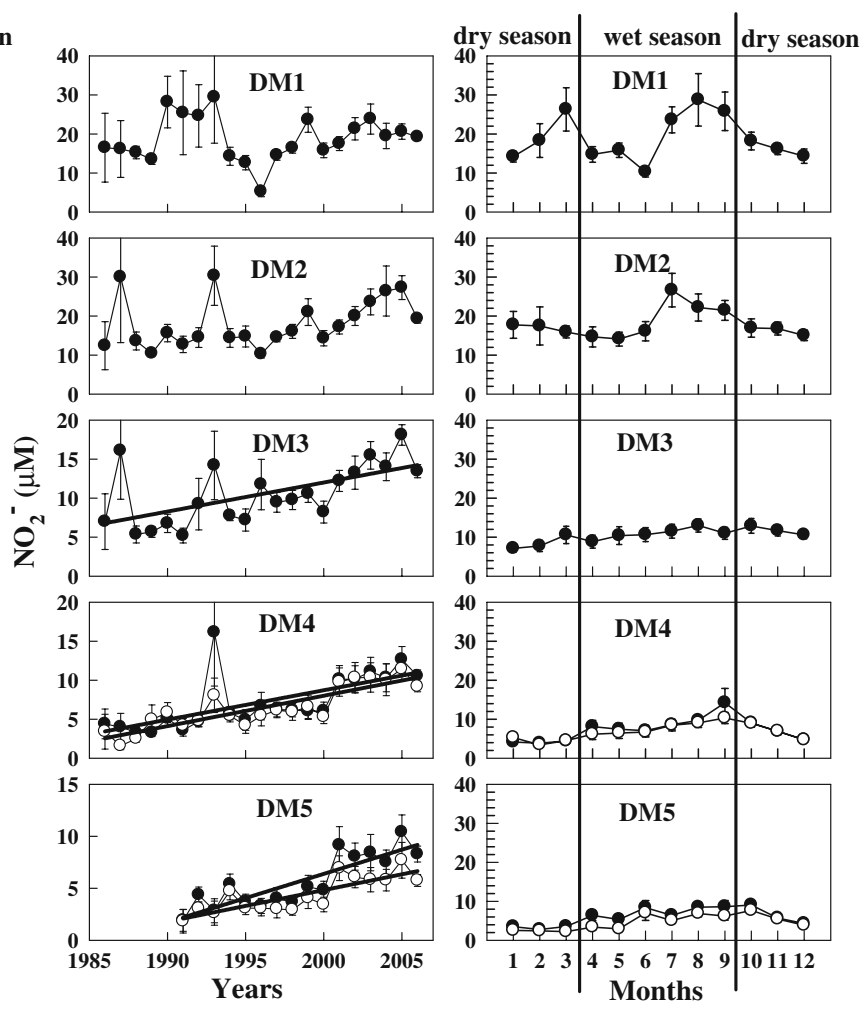

indicate \pm 1 SE and $n=6$ during $1986-1987$ and $n=12$ during 1988 2006 at all stations for the annual average data and $n=21$ for DM1 to DM4 and $n=16$ for DM5 for the monthly average data. Note the change in the scale on the $y$-axis

DM5 (Fig. 6, Table 1). No long-term trends were observed for $\mathrm{SiO}_{4}$ at all stations. However, $\mathrm{SiO}_{4}$ concentrations demonstrated the same seasonality pattern as $\mathrm{NO}_{3}$ (Fig. 5).

Annual average $\mathrm{PO}_{4}$ concentrations declined significantly $(p<0.05)$ by $0.56 \mu \mathrm{M}$ year $^{-1}$ at DM1 (Fig. 7, Table 1$)$. A significant $(p<0.05)$ long-term decreasing trend in TP concentration was observed at the rate of 0.12 to $1.76 \mu \mathrm{M}$ year $^{-1}$ at DM1 and at the surface and bottom at DM5 (Fig. 7, Table 1). There was no obvious seasonal variability in $\mathrm{PO}_{4}$ and TP. $\mathrm{PO}_{4}$ and TP concentrations exhibited the same inshore-offshore decreasing gradient as $\mathrm{NH}_{4}$.

DIN to $\mathrm{PO}_{4}$ molar ratios increased significantly and more than doubled from 12 to $25: 1$ during the 21-year period in the inner bay where DIN to $\mathrm{PO}_{4}$ ratios had no seasonal variability and fluctuated between $16: 1$ and $32: 1$ (Fig. 8). DIN to $\mathrm{PO}_{4}$ ratios increased from the inner to the outer bay in summer, with the lowest ratio (22:1) at DM1 and the highest ratio $(87: 1)$ at DM5. In contrast, DIN to $\mathrm{PO}_{4}$ ratios varied seasonally in the outer bay, with low ratios (19:1 to $45: 1)$ in winter and high ratios (37:1 to 87:1) in summer. There was a significant $(p<0.05)$ long-term increase in $\mathrm{DIN}$ to $\mathrm{SiO}_{4}$ at the surface and bottom in the outer bay driven by the twofold increase in DIN in the Pearl River water during the 21-year period (Fig. 8). 

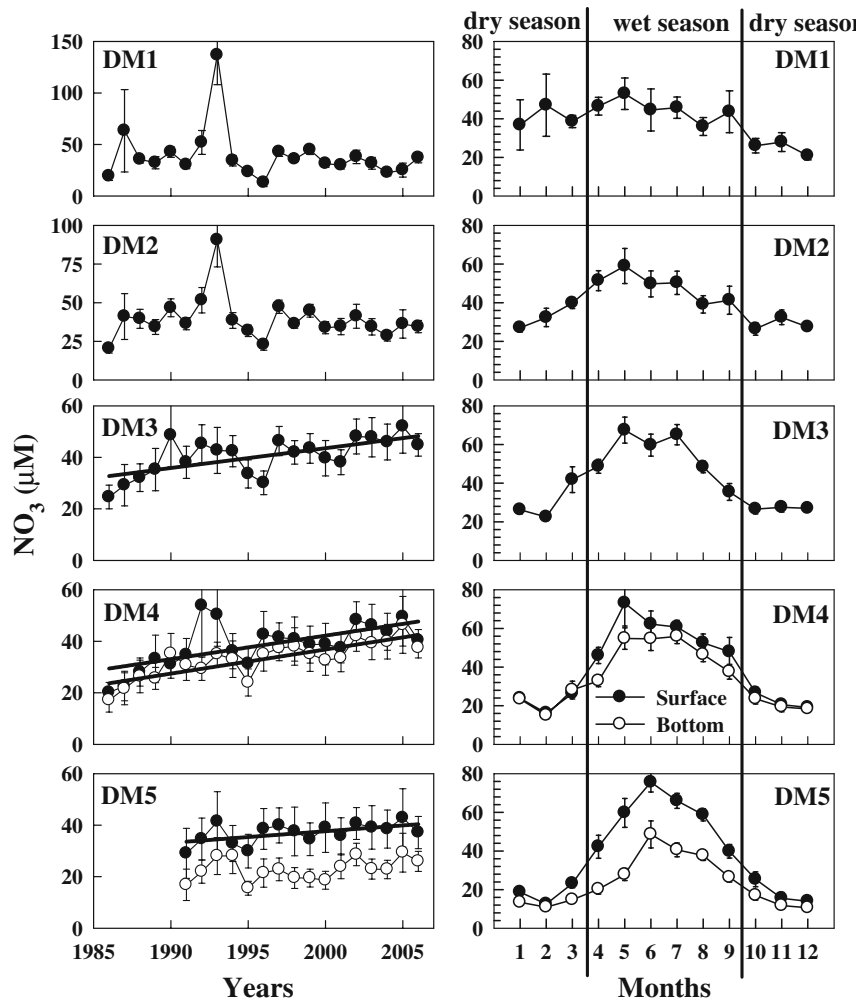

Fig. 5 Annual and monthly average $\mathrm{NO}_{3}$ and $\mathrm{SiO}_{4}$ concentrations at the surface (DM1, DM2, and DM3) and surface and bottom (DM4 and DM5) at five stations in Deep Bay during 1986-2006. The linear regression line represents a significant linear regression trend

\section{Chlorophyll and Suspended Solids}

There was a significant increase in Chl $a$ concentrations in the inner bay (DM1 and DM2) at the rate of 0.52$0.57 \mu \mathrm{g} \mathrm{L}^{-1}$ year $^{-1}$ (Table 1). In contrast, no trend was observed in the outer bay. Monthly water column average Chl $a$ concentrations were $<5 \mu \mathrm{g} \mathrm{L}^{-1}$ at DM4 and DM5 (Fig. 9). There was significantly higher Chl $a$ in summer and surprisingly high Chl $a$ in January in the inner bay.

There was a significant $(p<0.05)$ long-term trend in SS only at DM3. No seasonal variation in SS was observed at any of the stations. SS decreased spatially along the transect from the inner to the outer bay (Fig. 9).

\section{Dissolved Oxygen and Biochemical Oxygen Demand}

Annual average DO concentrations at the surface decreased significantly throughout the bay at the rate of 0.07 to $0.13 \mathrm{mg} \mathrm{L}^{-1}$ year $^{-1}$, as well as at the bottom at DM5 by $0.07 \mathrm{mg} \mathrm{L}^{-1}$ year $^{-1}$ (Fig. 10, Table 1). Likewise, seasonal variations in DO occurred at all stations with the lowest concentrations occurring in late summer, but hypoxia was seldom detected. DO concentrations increased from 3.0$6.4 \mathrm{mg} \mathrm{L}^{-1}$ in the inner to $3.9-7.8 \mathrm{mg} \mathrm{L}^{-1}$ in the outer bay
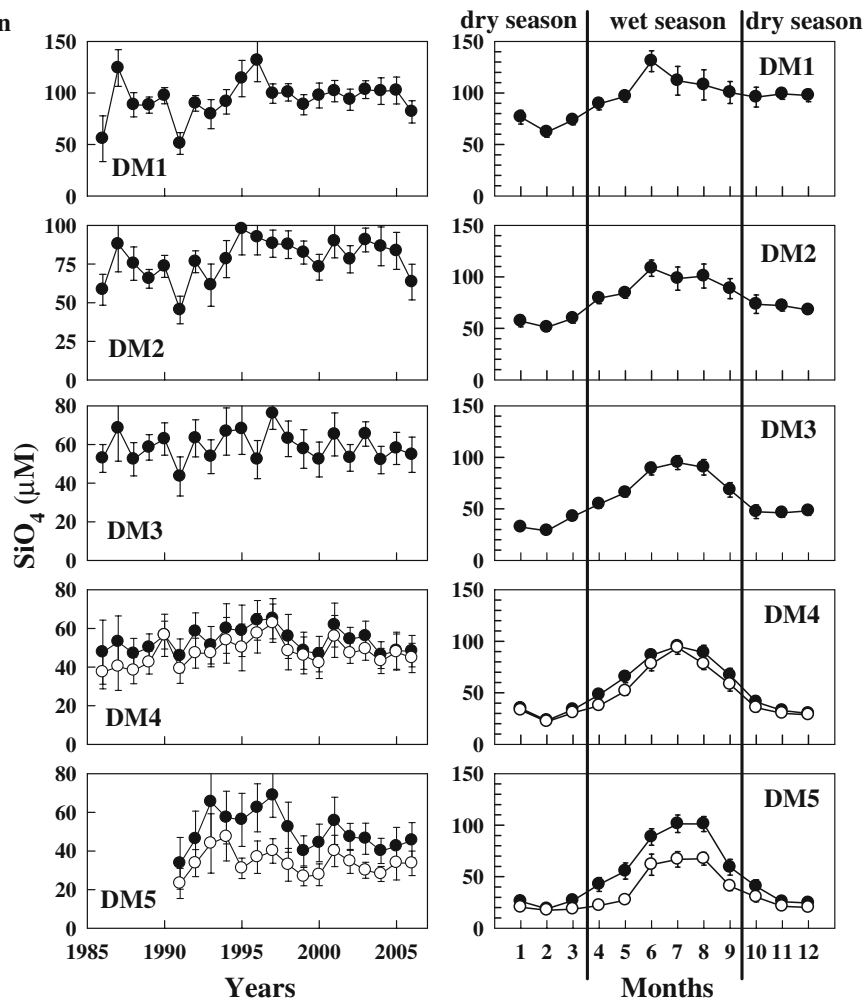

( $p<0.05)$. Vertical bars indicate \pm 1 SE and $n=6$ during 1986-1987 and $n=12$ during 1988-2006 at all stations for the annual average data and $n=21$ for DM1 to DM4 and $n=16$ for DM5 for the monthly average data. Note the change in the scale on the $y$-axis

(Fig. 10). There was a significant $(p<0.05)$ increasing trend in biochemical oxygen demand (BOD) at DM2 over the 21year time series (Fig. 10, Table 1).

\section{Secchi Disk Depth}

Annual average Secchi Disk Depth (SDD) decreased significantly at DM1 and DM4 by 0.03 and $0.07 \mathrm{~m}_{\text {year }}{ }^{-1}$, respectively (Fig. 11, Table 1). The monthly average SDD was very shallow and approximately $25 \%$ of the water depth. SDD increased along the bay's axis with the shallowest (usually $<0.6 \mathrm{~m}$ ) at DM1 and DM2, moderate $(<0.8 \mathrm{~m})$ at DM3, and the deepest $(<2 \mathrm{~m})$ at DM4 and DM5. Even if Chl $a$ and SS in the inner bay varied over summer, the monthly average of SDD did not vary accordingly.

\section{Rainfall}

Annual average rainfall increased significantly by $11 \mathrm{~mm}$ year $^{-1}$ in Hong Kong during 1960-2006, but there was no significant increase during the 21-year period from 1986 to 2006 (Fig. 12a, b). There was a significant negative correlation between surface salinity and rainfall at DM1 and DM2 (Fig. 12c, d). 

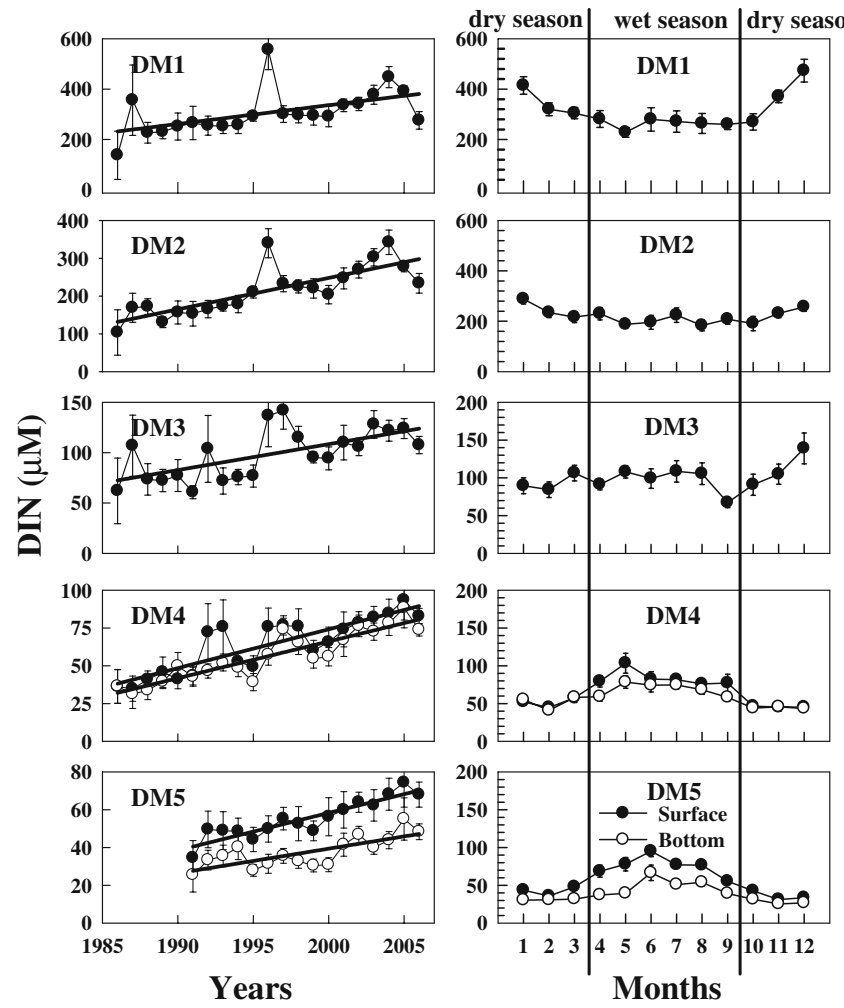

Fig. 6 Annual and monthly average $\mathrm{DIN}\left(=\mathrm{NH}_{4}+\mathrm{NO}_{2}{ }^{-}+\mathrm{NO}_{3}\right)$ and TN concentrations at the surface (DM1, DM2, and DM3) and surface and bottom (DM4 and DM5) at five stations in Deep Bay during 19862006. The linear regression line represents a significant linear regression

\section{Discussion}

Hong Kong waters experience seasonal variations with the invasion of coastal/oceanic water induced by the northeast monsoon winds in winter and by the typical two-layer estuarine circulation with the outflow of the Pearl River plume at the surface and the deep oceanic inflow at the bottom due to the southwest monsoon winds in summer (Watts 1983; Yin et al. 1999). As a result, there are marked seasonal and temporal variations in nutrients and phytoplankton biomass (Yin 2002; Xu et al. 2008). The outer part of Deep Bay is connected with the western edge of the Pearl River estuary and the western waters of Hong Kong. It is essential to understand the effects of the Pearl River discharge and the coastal/oceanic water on water quality of the Deep Bay for future management of the bay.

Inner Bay (DM1 and DM2): Long-Term and Seasonal Changes

Seasonal variations in salinity occurred throughout the bay. In winter, relatively high salinity (22-30) and a salinity gradient (up to 8 ) are evident along the bay's axis from 22 24 at DM1 to 29-31 at DM5, suggesting that the bay is
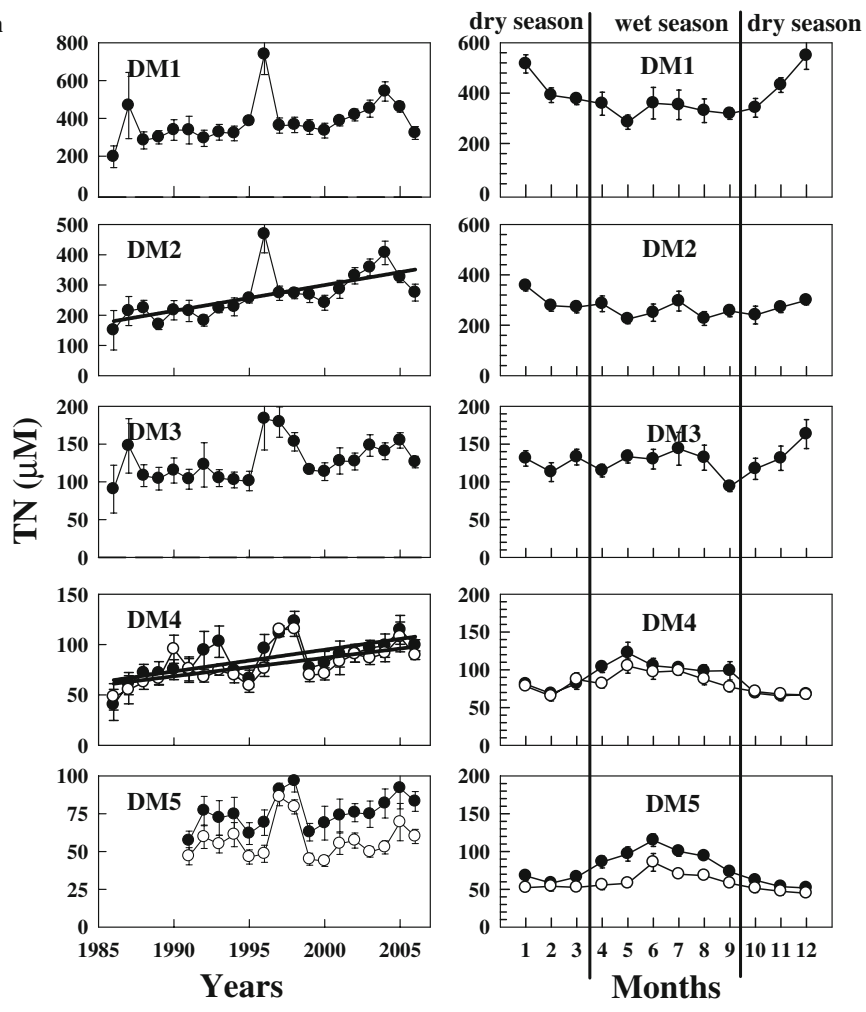

trend $(p<0.05)$. Vertical bars indicate \pm 1 SE and $n=6$ during 19861987 and $n=12$ during 1988-2006 at all stations for the annual average data and $n=21$ for DM1 to DM4 and $n=16$ for DM5 for the monthly average data. Note the change in the scale on the $y$-axis

subjected to the invasion of the coastal water from the China Coastal current with low nutrient concentrations (generally $<5 \mu \mathrm{M}$ DIN and $<0.5 \mu \mathrm{M} \mathrm{PO}_{4}$; Yin et al. 1999; Yin 2002). In summer, when rainfall is maximal, the salinity in the inner bay reaches a minimum due to dilution by rainfall and land runoff. Previous studies have shown that sewage effluent can be detected by $\mathrm{NH}_{4}$ and $\mathrm{PO}_{4}$ concentrations, as well as by low DIN to $\mathrm{PO}_{4}$ ratios $(\sim 10: 1$; $\mathrm{Xu}$ et al. 2008). In the inner bay that received high sewage discharge, monthly averaged DIN to $\mathrm{PO}_{4}$ ratios were generally within Redfield proportions (16:1 to 32:1) and exhibited no seasonality, implying that the Pearl River discharge, with a high DIN to $\mathrm{PO}_{4}$ ratio of $\sim 100: 1$ had little influence on the inner bay (DM1 and DM2). The low flushing rate ( 0.04 day $^{-1}$ or a residence time of $\sim 25$ days) in the inner bay (Lee and Qian 2003) likely explains the lack of influence by the invasion of Pearl River water in summer and coastal water in winter.

The shallow ( $2 \mathrm{~m}$ ) inner bay is vertically well mixed and most strongly affected by the sewage discharge at DM1. $\mathrm{NH}_{4}$ was the main contributor ( $\left.>50 \%\right)$ to the total nitrogen, as indicated by a significant correlation between $\mathrm{NH}_{4}$ and $\mathrm{TN}$, and the intercept of $<123 \mu \mathrm{M}$ (Fig. 13). The same results were observed for the correlation between TP and 

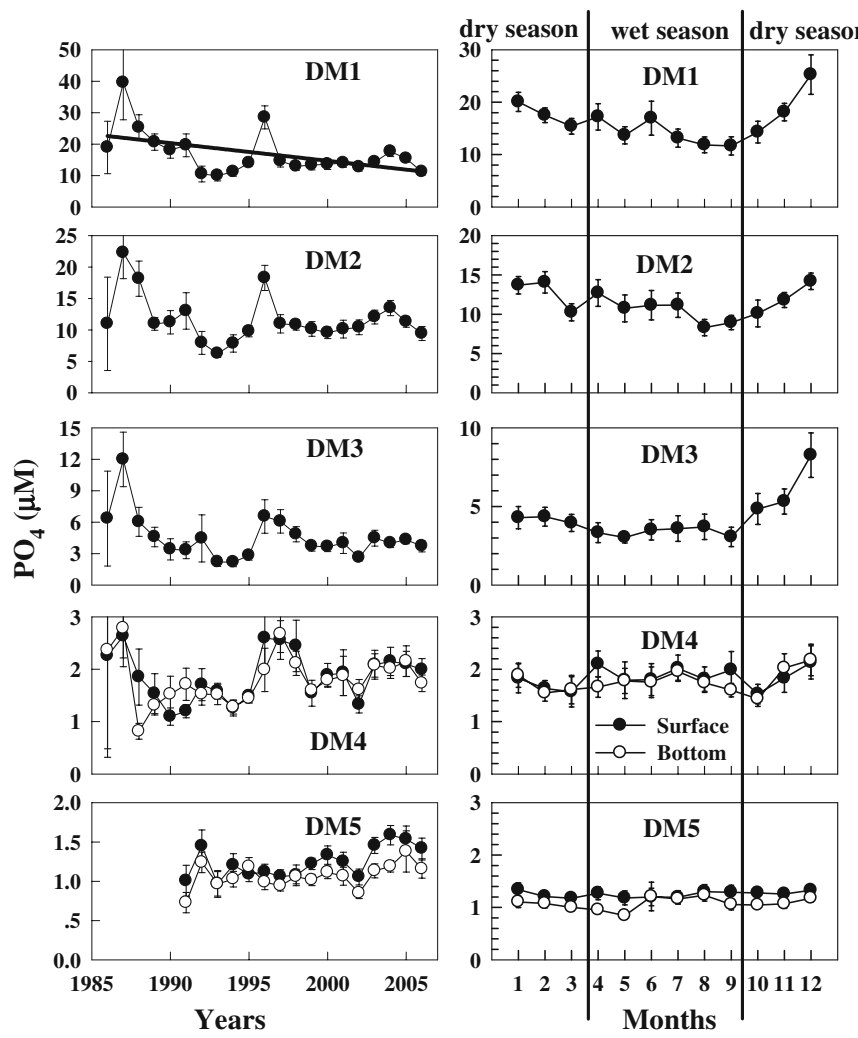

Fig. 7 Annual and monthly average $\mathrm{PO}_{4}$ and TP concentrations at the surface (DM1, DM2, and DM3) and surface and bottom (DM4 and DM5) at five stations in Deep Bay during 1986-2006. The linear regression line represents a significant linear regression trend

$\mathrm{PO}_{4}$ (Fig. 13). Elevated $\mathrm{NH}_{4}$ and $\mathrm{PO}_{4}$ concentrations are good indicators of inputs from sewage discharge (Xu et al. 2008). The long-term increase in $\mathrm{NH}_{4}$ concentration of $8.2 \mu \mathrm{M}$ year $^{-1}$ at DM1 is due to the increase in the sewage discharge and the increased human population of Shenzhen from $\sim 310,000$ in 1980 to over eight million today. The long-term $\mathrm{PO}_{4}$ reductions are related to the P-containing detergent ban in the 1990s and the improvement in sewage treatment. In turbid estuaries, sorption onto particles and colloidal aggregation often removes phosphate, especially when phosphate is high $(>5 \mu \mathrm{M}$; Sanders et al. 1997; Soetaert et al. 2006). As a result of the $\mathrm{PO}_{4}$ reduction and $\mathrm{NH}_{4}$ increase, the annual average DIN to $\mathrm{PO}_{4}$ ratio increased by over four times from 6:1 in 1986 to 25:1 in 2006. Based on the Redfield ratio of $16 \mathrm{~N}: 1 \mathrm{P}$, the potential limiting nutrient shifted from $\mathrm{N}$ to $\mathrm{P}$ limitation after the phosphate detergent ban. Similar increases in stoichiometric ratios of DIN to $\mathrm{PO}_{4}$ have been reported in many other estuaries following the improved treatment of sewage (Philippart et al. 2000; Nedwell et al. 2002; Soetaert et al. 2006).

In general, $\mathrm{NH}_{4}$ and $\mathrm{PO}_{4}$ loading from the sewage should remain relatively constant among all seasons. However, seasonal patterns showed that there was a sharp
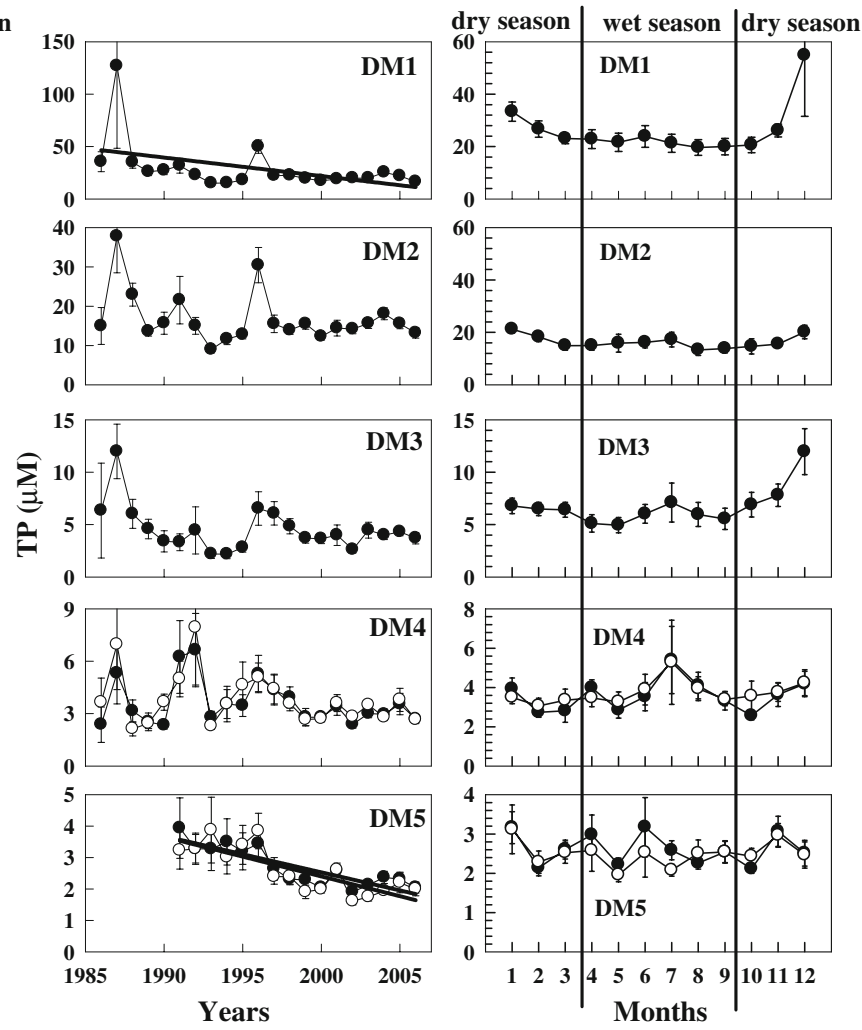

( $p<0.05$ ). Vertical bars indicate \pm 1 SE and $n=6$ during 1986-1987 and $n=12$ during 1988-2006 at all stations for the annual average data and $n=21$ for DM1 to DM4 and $n=16$ for DM5 for the monthly average data. Note the change in the scale on the $y$-axis

decline in $\mathrm{NH}_{4}$ and $\mathrm{PO}_{4}$ concentrations by 200 and $10 \mu \mathrm{M}$, respectively, in summer, relative to winter (Figs. 4 and 7). This was most likely due to dilution by rainfall and land runoff which is clearly evident by the very low salinity in July at DM1 and DM2. We estimate that the contribution of the phytoplankton uptake component to the observed decrease in $\mathrm{NH}_{4}$ and $\mathrm{PO}_{4}$ was very low: based on Redfield ratios, only $\sim 25 \mu \mathrm{M} \mathrm{N}$ and $<2 \mu \mathrm{M} \mathrm{PO}_{4}$ would be required to produce the $25 \mu \mathrm{g} \mathrm{Chl} \mathrm{L}{ }^{-1}$ of algal biomass measured in the water column in summer. The DON and PON concentrations, estimated from the intercept in the plots of TN vs DIN (Fig. 14), were relatively low $(20-22 \mu \mathrm{M})$. Hence, we speculated that a minor fraction of $\mathrm{NH}_{4}$ was converted to organic $\mathrm{N}$ through phytoplankton and bacterial uptake. The low $\mathrm{pH}$ value in the inner bay was more likely related to the input of low $\mathrm{pH}$ sewage. Unfortunately, this time series data set does not have bacterial abundance estimates. In addition, the decrease in $\mathrm{NH}_{4}$ due to nitrification, derived from the total increase of $30 \mu \mathrm{M} \mathrm{N}$ from $\mathrm{NO}_{3}$ and $\mathrm{NO}_{2}{ }^{-}$in summer, did not explain the $200-\mu \mathrm{M}$ reduction in $\mathrm{NH}_{4}$ (Fig. 4). Therefore, the reductions in $\mathrm{NH}_{4}$ and $\mathrm{PO}_{4}$ in summer were likely due mainly to dilution by rainfall and land runoff. This suggestion is also supported by the observation that TN 

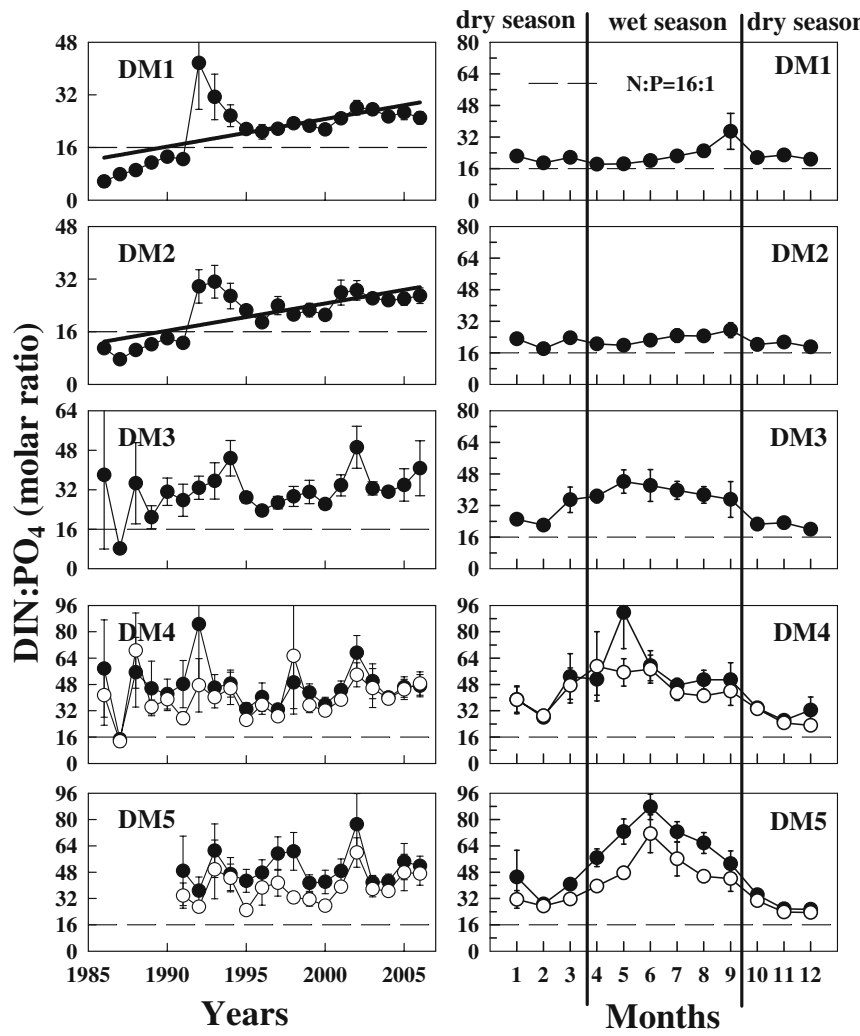

Fig. 8 Annual and monthly average $\mathrm{DIN}$ to $\mathrm{PO}_{4}$ ratios and $\mathrm{DIN}$ to $\mathrm{SiO}_{4}$ ratios at the surface (DM1, DM2, and DM3) and surface and bottom (DM4 and DM5) at five stations in Deep Bay during 1986-2006. The linear regression line represents a significant linear regression trend

concentrations were lower in the wet season than the dry season despite the increased input of $\mathrm{NO}_{3}$ from the land runoff in the wet season. The significant positive correlation between monthly average $\mathrm{NH}_{4}$ and salinity implied that freshwater input played an important role in the dilution of the sewage (Table 3).

Silicate is also an indicator of the freshwater inputs since it comes from terrestrial inputs through runoff. In summer, a maximum $\mathrm{Si}$ concentration of $140 \mu \mathrm{M}$ at DM1 and $120 \mu \mathrm{M}$ at DM2 was observed in the inner bay, higher than those $(\sim 100 \mu \mathrm{M})$ in the outer bay, implying that the summer maximum of $\mathrm{Si}$ concentrations in the inner bay was due to the high inputs from land runoff around the inner bay caused by the maximal rainfall during this period, rather than input from the Pearl River discharge. The runoff inputs also led to the similar increase in $\mathrm{NO}_{3}$ concentrations in summer. The lower peak in $\mathrm{NO}_{3}$ concentrations $(\sim 60 \mu \mathrm{M})$ in the inner bay than the $60-80 \mu \mathrm{M}$ in the outer bay (Fig. 5) was associated with a smaller contribution of nitrogen from agriculture to $\mathrm{NO}_{3}$ concentrations rather than from the Pearl River discharge. In summer, rainfall reaches a maximum monthly average value of $400 \mathrm{~mm}$, about ten times higher than winter (http://gb.weather.gov.hk/). The
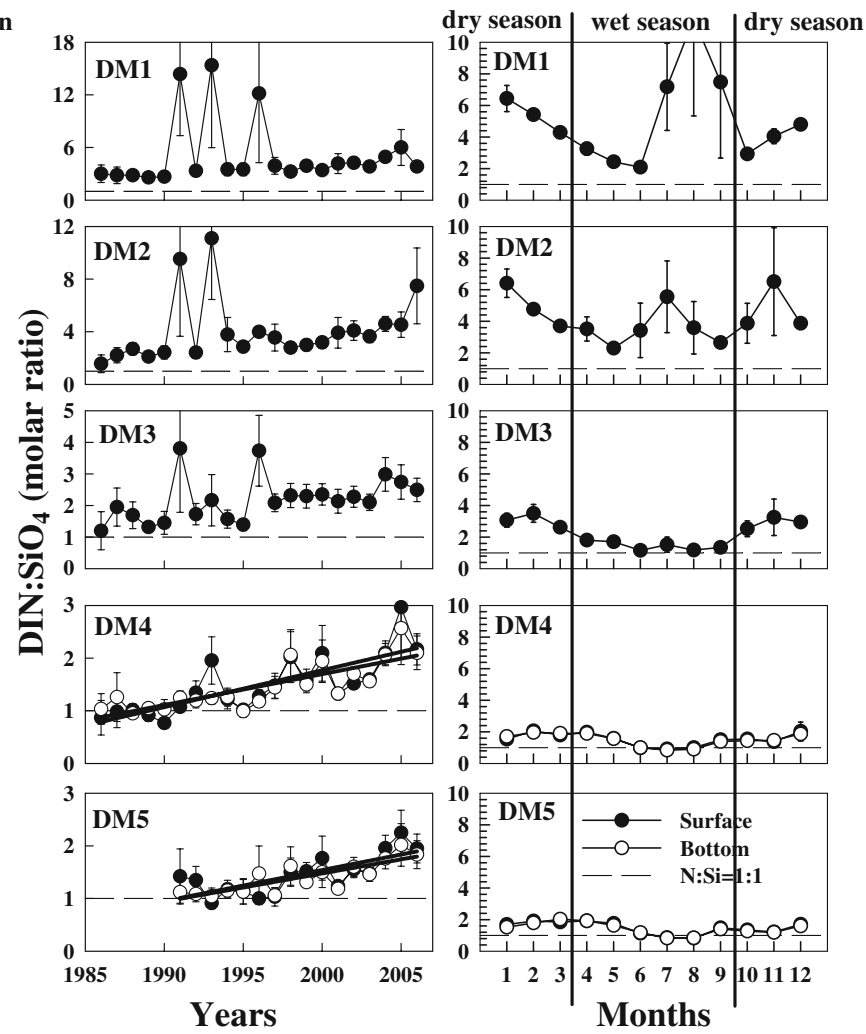

$(p<0.05)$. Vertical bars indicate \pm 1 SE and $n=6$ during $1986-1987$ and $n=12$ during 1988-2006 at all stations for the annual average data and $n=21$ for DM1 to DM4 and $n=16$ for DM5 for the monthly average data. Note the change in the scale on the $y$-axis

significant ( $p<0.05, t$ test) seasonal increase in Si concentrations suggested that the contribution of freshwater inputs into the inner bay increased dramatically in summer. The freshwater inputs resulted in a rapid decrease in salinity in the inner bay that is relatively enclosed and weakly flushed (Lee and Qian 2003). As a result, salinity was low $(\sim 5)$ in summer (Fig. 3). Similar findings have been reported in the Scheldt estuary in Belgium (Soetaert et al. 2006).

High Chl $a$ concentrations are a good indicator of eutrophication impacts (Pinckney et al. 1999; Paerl et al. 2006; Wong et al. 2009). Based on a $\mathrm{N}$ to Chl ratio of $1 \mu \mathrm{mol}: 1 \mu \mathrm{g}$, Chl $a$ concentrations were expected to be at least $200 \mu \mathrm{g} \mathrm{L}^{-1}$ all year, if no factors other than nutrients limited algal growth. Nonetheless, the maximum monthly average Chl $a$ concentrations were $<40 \mu \mathrm{g} \mathrm{L}^{-1}$ in the inner bay, much lower than expected. In addition, Chl $a$ concentrations were overestimated as the analytical method is sensitive to chlorophyll $b$ from chlorophytes. In this area, the SS concentrations were $20-100 \mathrm{mg} \mathrm{L}^{-1}$, much higher than a threshold value of $10 \mathrm{mg} \mathrm{L}^{-1}$ above which primary production starts to become light-limited (Ragueneau et al. 2002; Soetaert et al. 2006). We speculate that phytoplankton growth was limited by light because of vertical mixing (wind 

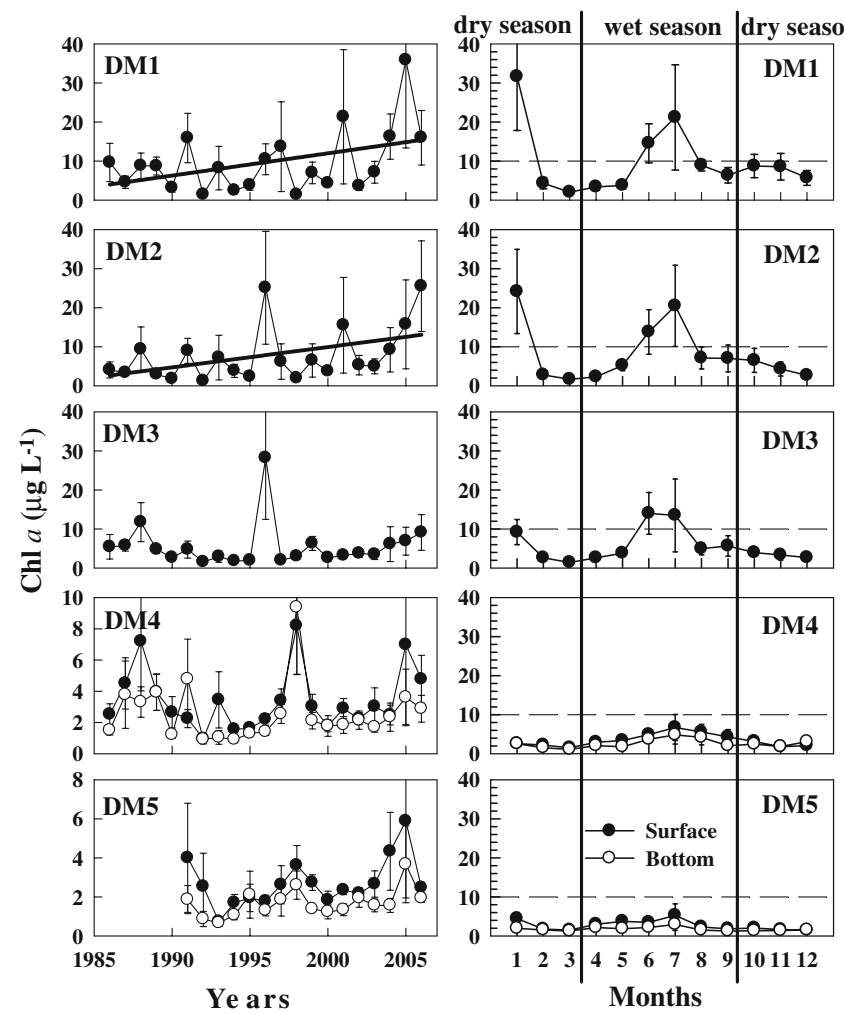

Fig. 9 Annual and monthly average Chl $a$ and SS (SS) concentrations at the surface (DM1, DM2, and DM3) and surface and bottom (DM4 and DM5) at five stations in Deep Bay during 1986-2006. The linear regression line represents a significant linear regression trend $(p<0.05)$. Vertical bars indicate \pm 1 SE and $n=6$ during 1986-1987

and tides) and the relatively high SS concentrations, since nutrients were not limiting in the inner bay and any change in DIN to $\mathrm{PO}_{4}$ ratios from 5-10:1 to $\sim 26: 1$ had little effect on phytoplankton growth. The resuspension of the sediment due to the shallow depth reduces the light penetration into the water column, as indicated by the shallow Secchi disk depth (Fig. 11). Light limitation for phytoplankton growth has often been reported in other turbid estuaries and coastal areas (Soetaert et al. 1994; Fisher et al. 1999; Colijin and Cadée 2003). In addition, the high phaeopigment to $\mathrm{Chl} a$ ratio (1.1 to $7.4 \mu \mathrm{g} / \mu \mathrm{g}$; Table 4 ) suggested active grazing, and bacterial consumption made an important contribution to Chl $a$ decomposition. A recent study indicates that microzooplankton grazing is one of the important factors regulating the phytoplankton growth in western waters next to Deep Bay (Chen et al. 2009). In the inner bay, the extremely high $\mathrm{NH}_{4}$ concentrations of 200 to $400 \mu \mathrm{M}$ also very likely inhibited phytoplankton growth to some extent based on previous studies that have shown that the inhibition of the algal growth occurs at $36 \mu \mathrm{M} \mathrm{NH} 4$ or lower (Natarajan 1970; Admiraal 1977; Thomas et al. 1980; Chang and McClean 1997; Yoshiyama and Sharp 2006). It is possible that the inner bay was in a hypereutrophic state where net heterotro-
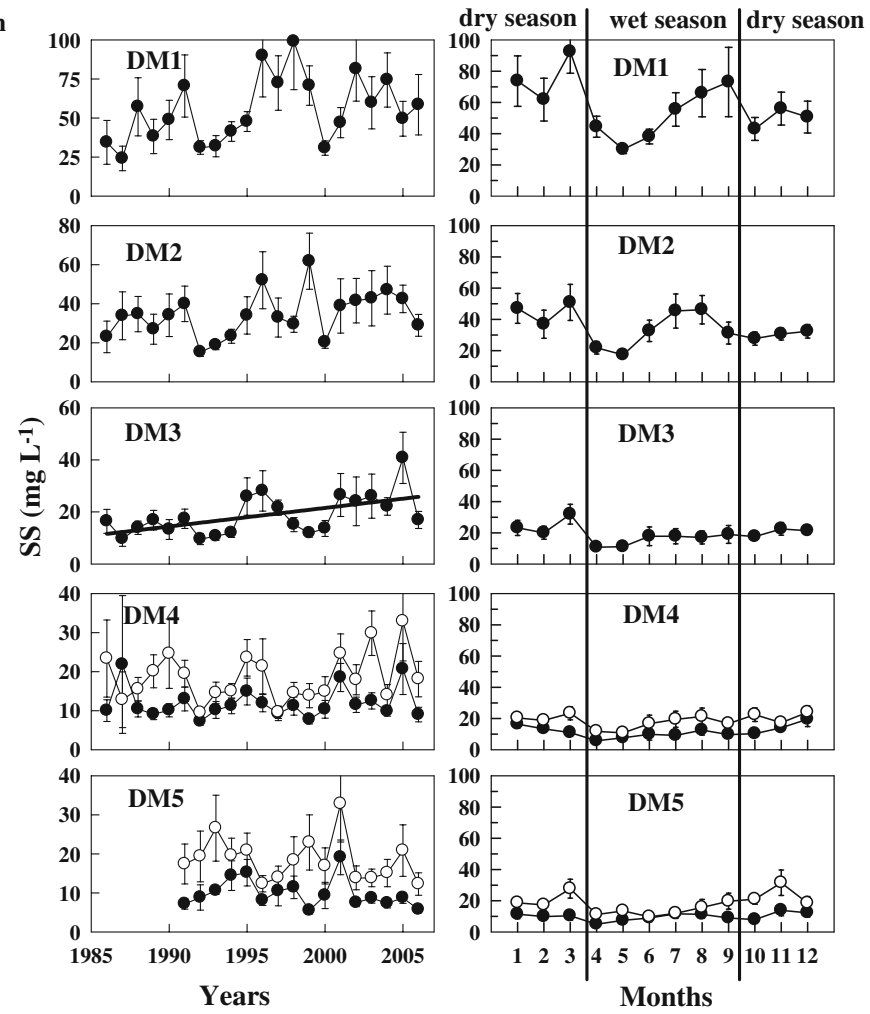

and $n=12$ during 1988-2006 at all stations for the annual average data and $n=21$ for DM1 to DM4 and $n=16$ for DM5 for the monthly average data. The dashed horizontal line represents the Chl a concentration $\left(10 \mu \mathrm{g} \mathrm{L}^{-1}\right)$ that indicates an algal bloom. Note the change in the scale on the $y$-axis

phy (bacterial production) dominates rather than autotrophy (algal production), but, without bacterial abundance data, it is not possible to confirm this hypothesis.

It is not clear why there was a significant long-term increase in Chl $a$ since nutrients were never limiting. It is possible that the increase in Chl $a$ is attributed to the decrease in salinity that was most likely caused by a combination of the increase in the freshwater sewage discharge from Shenzhen and the increase in rainfall by $28 \mathrm{~mm}$ year $^{-1}$ over the 21 -year period. The increased freshwater discharge generally produces two contrasting effects on the phytoplankton biomass. The increased freshwater discharge improves water stability by reducing vertical mixing and increasing stratification, which favors the accumulation of phytoplankton biomass. On the other hand, high freshwater discharge dilutes the phytoplankton biomass. The former was responsible for the increasing trend in Chl $a$ since modeling results showed that there was a low flushing rate $\left(0.04\right.$ day $\left.^{-1}\right)$ in the inner bay (Lee and Qian 2003). A more rapid decline in salinity in the inner bay relative to the outer bay generated a pronounced salinity gradient along the axis of the bay and probably increased the residence time by weakening water circula- 

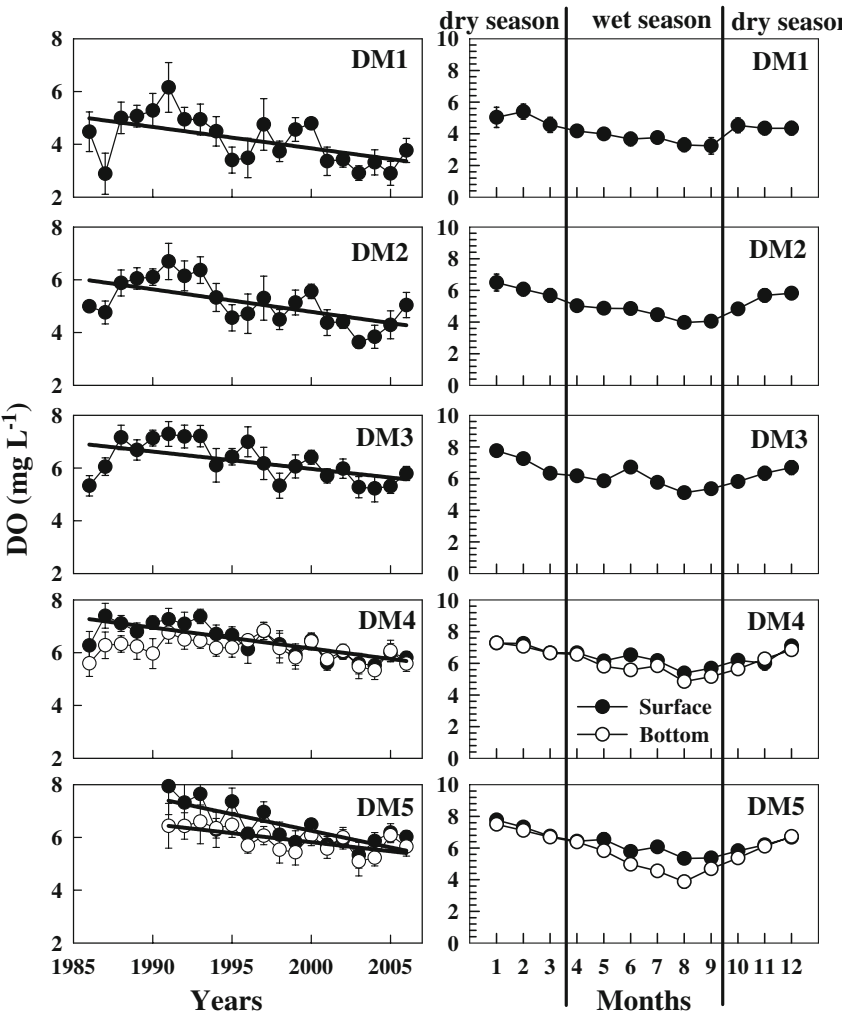

Fig. 10 Annual and monthly average dissolved oxygen $(D O)$ and BOD concentrations at the surface (DM1, DM2, and DM3) and surface and bottom (DM4 and DM5) at five stations in Deep Bay during 19862006. The linear regression line represents a significant linear regression

tion. In summer, salinity reached a minimum and increased water stability. Furthermore, the invasion of the Pearl River discharge has little effect in the inner bay. By comparison, the invasion of the relatively high salinity coastal water in winter into the outer bay produced a pronounced salinity gradient along the bay's axis, which increased the residence time in the inner bay. Thus, relatively high monthly averaged Chl $a$ concentrations $\left(>20 \mu \mathrm{g} \mathrm{L}^{-1}\right)$ occurred in both summer (June/July) and winter (January).

In the inner bay, hypoxic events $\left(<2 \mathrm{mg} \mathrm{DO} \mathrm{L}{ }^{-1}\right)$ did not appear to be frequent $(<10 \%$ of total sampling times). However, in this study, samples were taken at $1 \mathrm{~m}$ above the sediment during the daytime, and therefore near-bottom hypoxic events were probably underestimated since hypoxic events could develop just above the sediment and be more pronounced at nighttime. Despite this fact, the extent of hypoxia was overall not as severe as expected, and longterm hypoxic events were absent, which is mainly attributed to the shallow depth ( 2 m). Fisher et al. (1999) found that the extent of hypoxia was inversely correlated with the mean depth in regions of Chesapeake Bay. The long-term DO reductions were due to the increased domestic sewage loading with already low oxygen and high organic matter. More organic matter inputs into this area due to the
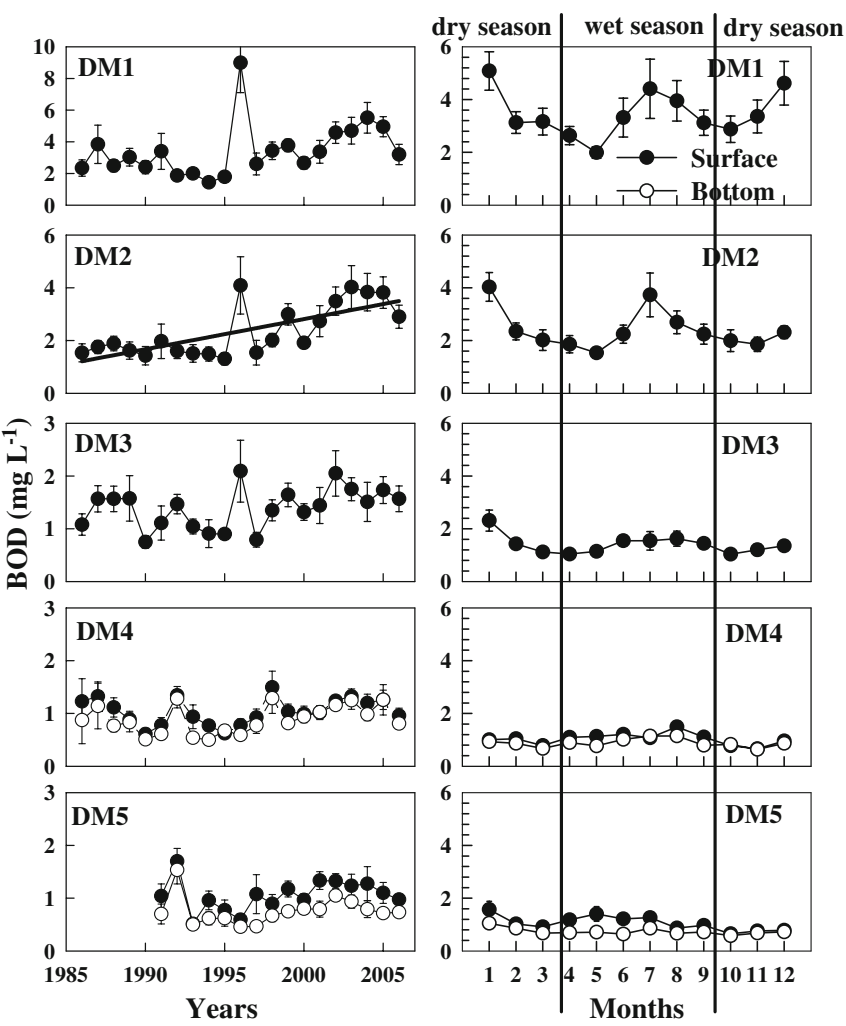

trend $(p<0.05)$. Vertical bars indicate \pm 1 SE and $n=6$ during 1986 1987 and $n=12$ during 1988-2006 at all stations for the annual average data and $n=21$ for DM1 to DM4 and $n=16$ for DM5 for the monthly average data. Note the change in the scale on the $y$-axis

increased sewage effluent stimulated bacterial respiration, leading to lower DO, as indicated by the increasing trend in $\mathrm{BOD}$ at DM2. Enhanced BOD was considered to be responsible for the decrease in DO in many other estuaries (St. John 1990; Brosnan and O'Shea 1996). Meanwhile, an increase in the freshwater loading was partially responsible for the decreased DO by weakening water circulation and increasing the water stratification. The significant decreasing trend in DO concentration indicates the need for further sewage treatment for Shenzhen.

Seasonal variations in DO were observed with low concentrations in summer and maximum values in winter. The DO minimum in summer was related to higher temperature, as indicated by a significant correlation between monthly average DO and temperature (Table 5). In summer, the high water temperature resulted in elevated bacterial respiration, as well as a decrease in solubility of DO in the water column (Truesdal et al. 1955; Carpenter 1966).

Outer Bay (DM3 to DM5): Long-Term and Seasonal Changes

At the deeper stations (DM4 and DM5) in the outer bay, the bottom temperature rose significantly in summer and winter 
Fig. 11 Annual and monthly average Secchi disk depths at five stations in Deep Bay during 1998-2006. The linear regression line represents a significant linear regression trend $(p<0.05)$. Vertical bars indicate \pm 1 SE and $n=9$

Fig. 12 Annual average rainfall in Hong Kong waters during 1960 to 2006 (a) and 19862006 (b). A significant linear regression trend is denoted by $p<0.05$. Concentrations and linear regressions of annual average salinity vs rainfall for the surface in the inner bay at DM1 (c) and DM2 (d) during 1986-2006
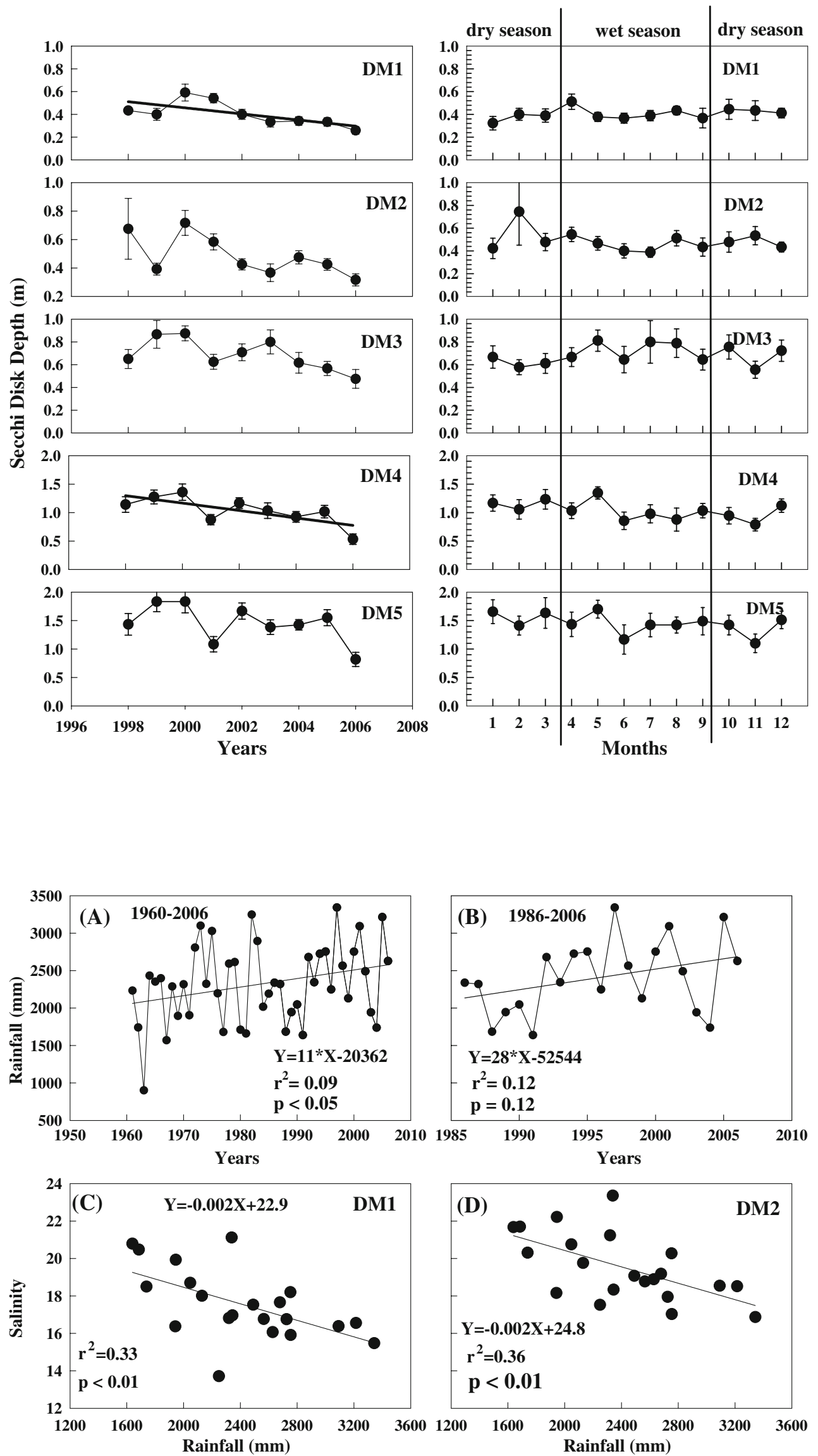
Fig. 13 Concentrations and linear regressions of $\mathrm{TN}$ vs $\mathrm{NH}_{4}$ and TP $\mathrm{vs} \mathrm{PO}_{4}$ for the surface in the inner bay (DM1 and DM2) from the time series from 1986 to 2006
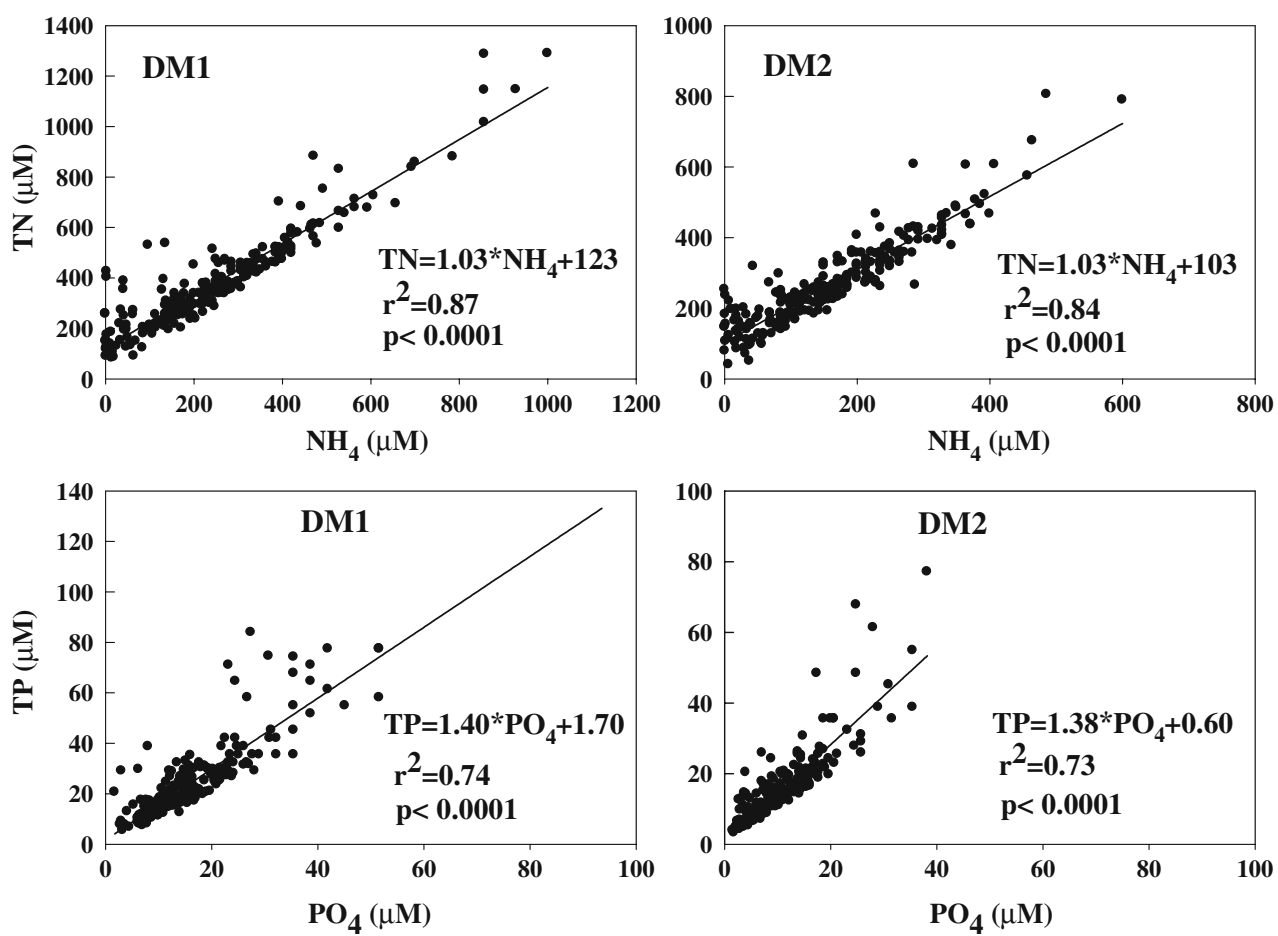

during the last two decades, and the largest increase occurred in winter, as indicated by the higher rate of increase $\left(0.23^{\circ} \mathrm{C}\right.$ year $\left.^{-1}\right)$ at DM5. The long-term increase $\left(0.5-2^{\circ} \mathrm{C}\right)$ in the surface and bottom temperature during the last two decades was observed in other waters (e.g., western and southern waters, Victoria Harbor) of Hong Kong (Ho 2007). The rate of increase $\left(0.14\right.$ in summer and $0.23^{\circ} \mathrm{C}$ year $^{-1}$ in winter) in the bottom temperature at DM5 was greater than at DM4 (Table 2). The slower rate of increase at DM4 was possibly attributed to strong vertical mixing due to shallow depth $(4 \mathrm{~m})$, as indicated by the small difference between surface and bottom salinity (Fig. 2). The long-term increase in temperature reflected climatic changes in Hong Kong waters which affects ecological responses to eutrophication (Howarth et al. 2000).

In July, when the Pearl River discharge is maximal, the salinity reached a minimum due to dilution by the Pearl River discharge in the outer bay, especially at DM5. The Pearl River discharge has high $\mathrm{NO}_{3}(\sim 100 \mu \mathrm{M})$ and $\mathrm{SiO}_{4}(>100 \mu \mathrm{M})$ concentrations, as well as high DIN to $\mathrm{PO}_{4}$ ratios $(\sim 100: 1$; Yin et al. 2000), since the nutrient inputs are from agriculture, rainfall, and groundwater as well as sewage. In the outer bay, monthly averaged DIN to $\mathrm{PO}_{4}$ ratios demonstrated strong seasonal variability with a maximum DIN to $\mathrm{PO}_{4}$ ratio of $\sim 90: 1$ in June at DM5 (Fig. 8). These results indicated that the outer bay is influenced by the Pearl River discharge with high DIN in summer. However, in winter, it is influenced by the invasion of coastal water with low DIN. This suggestion is supported by the high flushing rate $\left(0.2\right.$ day $^{-1}$ or a residence time of $\sim 5$ days $)$ in the outer bay (Lee and Qian 2003).

A threefold or more increase in $\mathrm{NH}_{4}$ at the surface was observed (from 3-10 to 20-31 $\mu \mathrm{M}$ ) at the outer bay stations (DM4 and DM5, respectively) in response to the increased sewage loading during the last 21 years. $\mathrm{PO}_{4}$ concentrations exhibited no seasonal pattern in the outer bay. At DM5, $\mathrm{PO}_{4}$ concentrations $(\sim 1 \mu \mathrm{M})$ were similar to that in the Pearl River discharge (Yin et al. 2000).

The increase in $\mathrm{NO}_{3}$, but no increase in $\mathrm{SiO}_{4}$, is consistent with the recently documented long-term increasing trend for $\mathrm{NO}_{3}$ in the Pearl River discharge during the last two decades (Xu et al. 2008). Significant correlations between salinity and $\mathrm{NO}_{3}$ or $\mathrm{SiO}_{4}$ in the outer bay (Fig. 15) suggest that these nutrients come from the Pearl River discharge and that they have both behaved conservatively during the last two decades. $\mathrm{NO}_{3}$ and $\mathrm{SiO}_{4}$ concentrations in the Pearl River discharge, estimated by the intercept concentrations, are similar to the observed values $\left(\mathrm{NO}_{3} 75\right.$ $\left.100 \mu \mathrm{M} ; \mathrm{SiO}_{4} 130-140 \mu \mathrm{M}\right)$ in the near-zero salinity end member in the Pearl River estuary (Yin et al. 2000, 2001; Cai et al. 2004). These results also agree with the observations in the adjacent western waters (Xu et al. 2008). The long-term increasing trend in DIN, accompanied by the increase in DIN to $\mathrm{SiO}_{4}$ ratios as a result of the increase in $\mathrm{NH}_{4}$ and $\mathrm{NO}_{3}$, suggests that eutrophication impacts are becoming more severe, and nutrient ratios are being altered in this area during the last two decades. Similar to the inner bay, DIN was the main component 
Fig. 14 Concentrations and linear regressions of TN vs DIN for the surface for five stations from the time series from 1986 to 2006. Intercept $=\mathrm{DON}+\mathrm{PON}$
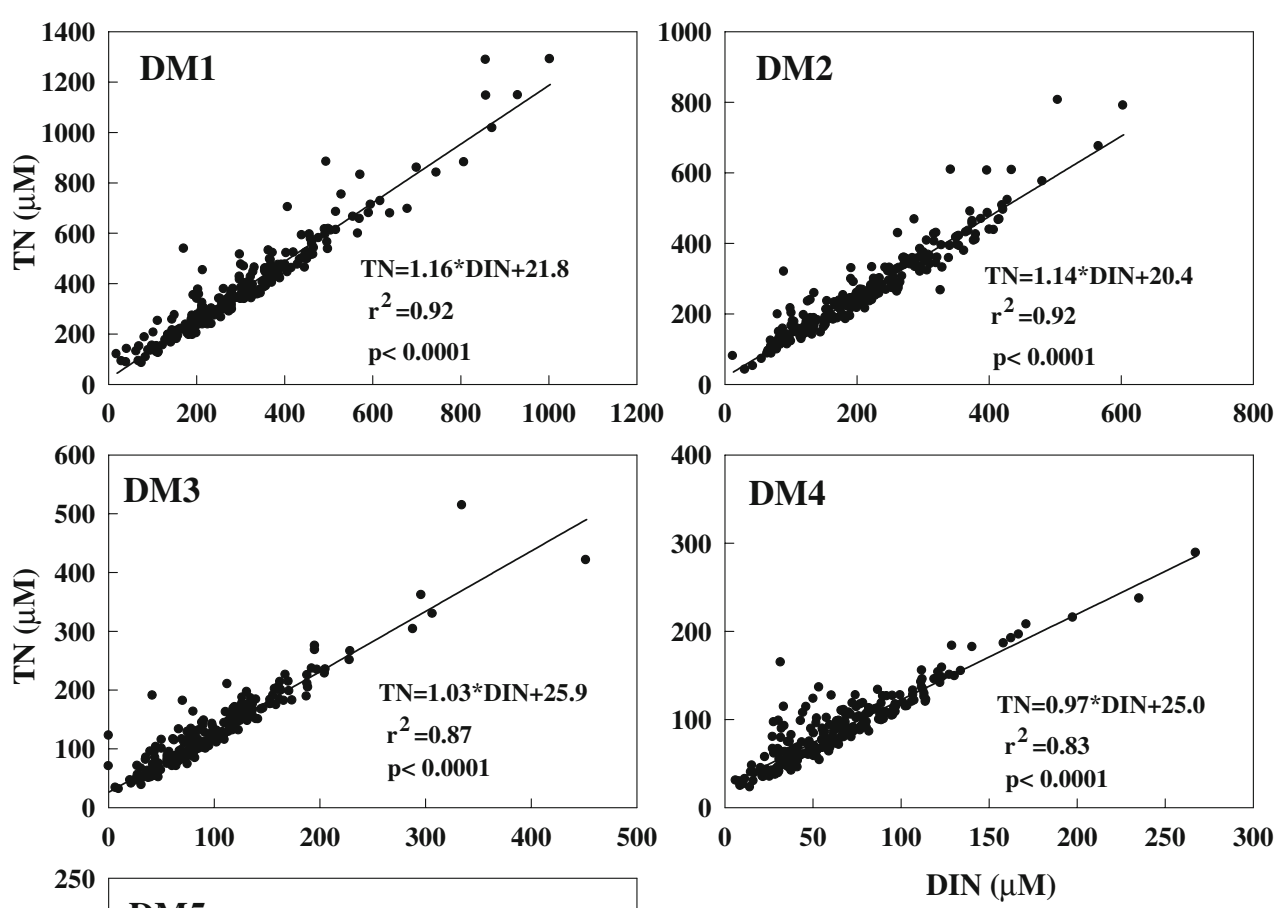

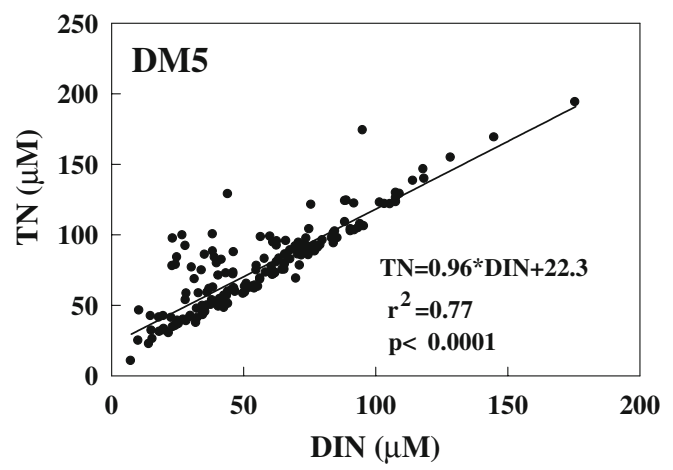

$(>50 \%)$ of $\mathrm{TN}$ in the outer bay, indicating that there was little contribution from particulate organic N. Annual and monthly average DIN to $\mathrm{PO}_{4}$ ratios were greater than the Redfield ratio of $16 \mathrm{~N}: 1 \mathrm{P}$, suggesting that $\mathrm{P}$ was deficient relative to $\mathrm{N}$ in this region. However, the ambient $\mathrm{PO}_{4}$ concentrations remained $>1 \mu \mathrm{M}$, well above the threshold value for $\mathrm{P}$ limitation $\left(\mathrm{PO}_{4} \approx 0.1 \mu \mathrm{M}\right.$, Justić et al. 1995), implying that actual $\mathrm{P}$ limitation rarely occurred.
Table 4 Phaeopigment to Chl $a$ ratio $(\mu \mathrm{g} / \mu \mathrm{g})$ at the surface in Deep Bay during 1986-2006
Error bar represents $\pm 1 \mathrm{SE}, n=$ 21 for DM1, DM2, DM3, and DM4 and $n=16$ for DM5

\begin{tabular}{|c|c|c|c|c|c|}
\hline Month & DM1 & DM2 & DM3 & DM4 & DM5 \\
\hline 1 & $4.29 \pm 1.68$ & $4.61 \pm 1.76$ & $1.37 \pm 0.51$ & $1.74 \pm 0.75$ & $1.63 \pm 0.72$ \\
\hline 2 & $3.61 \pm 0.91$ & $3.19 \pm 0.81$ & $2.11 \pm 0.87$ & $0.87 \pm 0.24$ & $0.57 \pm 0.15$ \\
\hline 3 & $4.23 \pm 1.34$ & $3.64 \pm 1.40$ & $1.83 \pm 0.69$ & $1.03 \pm 0.27$ & $0.60 \pm 0.09$ \\
\hline 4 & $4.23 \pm 1.81$ & $1.97 \pm 0.58$ & $1.02 \pm 0.24$ & $1.04 \pm 0.37$ & $0.52 \pm 0.13$ \\
\hline 5 & $1.94 \pm 0.61$ & $1.11 \pm 0.24$ & $0.78 \pm 0.15$ & $1.07 \pm 0.29$ & $1.06 \pm 0.26$ \\
\hline 6 & $1.72 \pm 0.57$ & $2.09 \pm 0.58$ & $1.40 \pm 0.61$ & $1.03 \pm 0.22$ & $1.60 \pm 1.04$ \\
\hline 7 & $4.61 \pm 2.12$ & $2.19 \pm 0.59$ & $1.83 \pm 0.71$ & $2.91 \pm 0.83$ & $1.56 \pm 0.59$ \\
\hline 8 & $1.62 \pm 0.57$ & $2.04 \pm 0.48$ & $0.89 \pm 0.23$ & $1.66 \pm 0.43$ & $1.12 \pm 0.43$ \\
\hline 9 & $7.44 \pm 4.23$ & $3.31 \pm 1.19$ & $2.07 \pm 0.90$ & $1.03 \pm 0.27$ & $1.83 \pm 0.71$ \\
\hline 10 & $1.68 \pm 0.71$ & $1.82 \pm 0.77$ & $1.86 \pm 1.05$ & $0.94 \pm 0.29$ & $1.62 \pm 0.71$ \\
\hline 11 & $5.45 \pm 4.42$ & $2.56 \pm 0.92$ & $0.83 \pm 0.16$ & $1.24 \pm 0.64$ & $1.40 \pm 0.54$ \\
\hline 12 & $2.32 \pm 0.54$ & $2.24 \pm 0.60$ & $2.22 \pm 0.95$ & $1.04 \pm 0.27$ & $0.92 \pm 0.36$ \\
\hline
\end{tabular}


Table 5 Correlation coefficients, $r$, derived from a Pearson test, between monthly average $\mathrm{NH}_{4}$ and salinity and $\mathrm{DO}$ and temperature for the inner bay (DM1 and DM2) from 1986 to 2006; $n=12$ (months in a year)

\begin{tabular}{lllllll}
\hline Stations & Variable & \multicolumn{2}{l}{ Salinity } & & Variable & \multicolumn{2}{l}{ Temperature } \\
\cline { 3 - 4 } & & & & $n$ & \multicolumn{2}{c}{$r$} \\
\hline DM1 & $\mathrm{NH}_{4}$ & 12 & $0.59^{\mathrm{a}}$ & DO & 12 & $-0.86^{\mathrm{b}}$ \\
$\mathrm{DM} 2$ & & 12 & $0.71^{\mathrm{a}}$ & & 12 & $-0.94^{\mathrm{b}}$ \\
\hline
\end{tabular}

${ }^{\text {a }}$ Significant correlation at the 0.05 level

${ }^{\mathrm{b}}$ Significant correlation at the 0.01 level

In the outer bay, annual and monthly average Chl $a$ concentrations in the water column were usually $<10 \mu \mathrm{g} \mathrm{L}^{-1}$ and lower than expected. Phytoplankton biomass exhibited no long-term or seasonal trends, as well as no response to long-term and seasonal changes in nutrients. Organic nitrogen (DON and PON) was 22 to $26 \mu \mathrm{M}$ (Fig. 14), comparable to those in the inner bay and $<50 \%$ of the total $\mathrm{N}$. These results indicated that the factor regulating phytoplankton growth and biomass accumulation was not nutrient concentrations but physical processes and grazing. This suggestion was supported by the conservative mixing in the transport of $\mathrm{NO}_{3}$ and $\mathrm{SiO}_{4}$. In the outer bay, the high flushing rate was likely responsible for low phytoplankton biomass (Lee and Qian 2003). The influence of physical processes on the regulation of phytoplankton growth was also observed in the nearby western waters of Hong Kong (Xu et al. 2008, 2009).

In the outer bay, the long-term and seasonal patterns of DO were similar to the inner bay, suggesting that DO concentrations were mainly affected by the advection of low oxygen water from the inner bay. The decrease in DO is not as severe as observed in the inner bay. The lowest bottom DO occurred in summer because of the strong thermohaline stratification and higher bacterial respiration induced by higher water temperatures.
Spatial Variations in Water Quality

There was a strong gradient in water quality from the inner to the outer bay in response to the sewage inputs from Shenzhen. High $\mathrm{NH}_{4}, \mathrm{PO}_{4}$, and $\mathrm{BOD}$ were observed, as well as low DO concentrations in the inner bay where the maximum annual water column averaged $\mathrm{NH}_{4}$ and $\mathrm{PO}_{4}$ concentrations exceeded 500 and $39 \mu \mathrm{M}$, respectively. In contrast, $\mathrm{NH}_{4}$ and $\mathrm{PO}_{4}$ concentrations decreased sharply from the inner to the outer bay because of dilution due to the invasion of Pearl River water in summer and coastal water in winter. At DM5 (outer bay), $\mathrm{NH}_{4}$ and $\mathrm{PO}_{4}$ concentrations were only $\sim 5 \%$ of those at DM1 (inner bay), implying that the sewage discharge at DM1 had little effect on the water quality outside the bay. This suggestion is supported by the relatively low $\mathrm{NH}_{4}$ and $\mathrm{PO}_{4}$ concentrations in western Hong Kong waters adjacent to Deep Bay (EPD 2006). Correspondingly, DO concentrations increased from an annual and monthly average value of $3 \mathrm{mg} \mathrm{L}^{-1}$ in the inner bay to $>4.5 \mathrm{mg} \mathrm{L}^{-1}$ in the outer bay, possibly because of mixing with high oxygen water from the Pearl River discharge in summer and the coastal water in winter.

\section{Summary}

Deep Bay can be divided into the inner bay (DM1 and DM2) and the outer bay (DM3 to DM5). The inner bay has a relatively small volume of water since it is only $2 \mathrm{~m}$ deep and a long residence time of about 25 days. Therefore, high rainfall and runoff in summer reduces the salinity from $\sim 25$ in winter to 7 in July. Similarly, the climatic effect of the significant increase in rainfall $\left(11 \mathrm{~mm}\right.$ year $\left.^{-1}\right)$ over the last 45 years increased stratification and reduced light limitation, which explained the increase in $\mathrm{Chl}$ over the 21-year period, since nutrients are not limiting. Phytoplankton growth was likely limited by grazing and light due to vertical mixing and SS, as well as by ammonium toxicity. The lowest DO (monthly average of $\sim 3.0 \mathrm{mg} \mathrm{L}^{-1}$ ) occurred in the inner bay near the sewage effluent discharge site.
Fig. 15 Concentrations and linear regressions of $\mathrm{NO}_{3}$ and $\mathrm{SiO}_{4}$ versus salinity for the surface for the outer bay (DM5) from the time series from 1991 to 2006
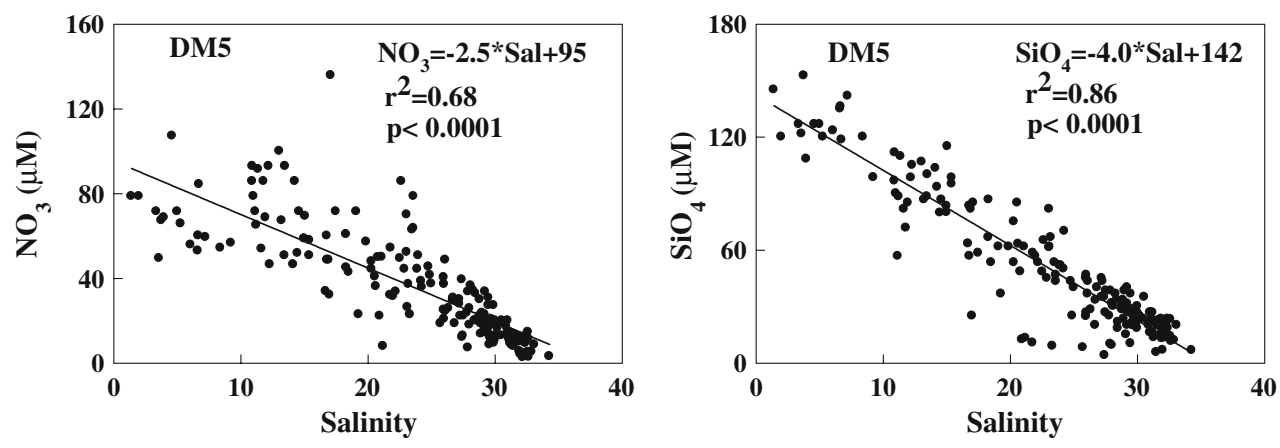
Long-term hypoxic events were not frequent $(<10 \%)$ throughout the bay due to the shallow depth and mixing. Information on bacterial biomass should also be considered in future monitoring.

The outer bay experienced seasonal exchange between the Pearl River discharge with high DIN to $\mathrm{PO}_{4}$ ratios in summer and the coastal water with low DIN to $\mathrm{PO}_{4}$ ratios in winter. The twofold increase in $\mathrm{NO}_{3}$ and DIN and no significant increase in $\mathrm{PO}_{4}$ in the outermost station in the bay confirm previous findings that the $>20$-year increase in the $\mathrm{N}$ loading from the Pearl River has shifted the receiving waters of the Pearl River into potential P limitation especially in summer. Phytoplankton growth was primarily regulated by the dilution of the Pearl River discharge and possibly grazing in the outer bay. Hypoxia seldom occurred in the outer bay. However, DO concentrations showed a significant long-term reduction from 0.07 to $0.13 \mathrm{mg} \mathrm{L}^{-1}$ year $^{-1}$ throughout the bay in response to the increase in sewage loading and suggests that further sewage treatment is warranted in the future. Thus, in order to understand the long-term changes in Deep Bay, it is necessary to consider the climatic effects of increased rainfall along with the increase in anthropogenic nutrient loading.

Acknowledgements Financial support for this research was provided by the University Grants Council of Hong Kong AoE project (AoE/ P-04/0401). We thank the Hong Kong Government EPD for permitting us to use their water quality monitoring data for this publication.

\section{References}

Admiraal, W. 1977. Tolerance of estuarine benthic diatoms to high concentrations of ammonia, nitrite ion, nitrate ion, and orthophosphate. Marine Biology 43: 307-315.

Bachmann, R.W., J.E. Cloern, and R.E. Heckey. 2006. Eutrophication of freshwater and marine ecosystems. Limnology and Oceanography 51: 351-800.

Ball, P.W., A. Macdonald, K. Pugh, and A.C. Edwards. 1995. Long term nutrient enrichment of an estuarine system: Ythan, Scotland (1958-1993). Environmental Pollution 90: 311-321.

Boynton, W.R., J.H. Garber, R. Summers, and W.M. Kemp. 1995. Inputs, transformations, and transport of $\mathrm{N}$ and $\mathrm{P}$ in Chesapeake Bay and selected tributaries. Estuaries 18: 285-314.

Brosnan, T.M., and M.L. O'Shea. 1996. Long term improvements in water quality due to sewage abatement in the lower Hudson River. Estuaries 19: 890-900.

Cai, W.J., M.H. Dai, Y.C. Wang, W.D. Zhai, T. Huang, S.T. Chen, F. Zhang, Z.Z. Chen, and Z.H. Wang. 2004. The biogeochemistry of inorganic carbon and nutrients in the Pearl River estuary and adjacent Northern South China Sea. Continental Shelf Research 24: 1301-1319.

Carpenter, J.H. 1966. New measurements of oxygen solubility in pure and natural water. Limnology and Oceanography 11: 264-277.

Chang, F.H., and M. Mcclean. 1997. Growth responses of Alexandrium minutum (Dinophyceae) as a function of three different nitrogen sources and irradiance. New Zealand Journal of Marine and Freshwater Research 31: 1-7.
Chen, B., H. Liu, M.R. Landry, M. Chen, J. Sun, L. Shek, X. Chen, and P.J. Harrison. 2009. Estuarine nutrient loading affects phytoplankton growth microzooplankton grazing at two contrasting sites in Hong Kong coastal waters. Marine Ecology Progress Series 379: 77-90.

Cloern, J.E. 1999. The relative importance of light and nutrient limitation of phytoplankton growth: A simple index of coastal ecosystem sensitivity to nutrient enrichment. Aquatic Ecology 33: $3-16$.

Cloern, J.E. 2001. Our evolving conceptual model of the coastal eutrophication problem. Marine Ecology Progress Series 210: 223-253.

Colijin, F., and G.C. Cadée. 2003. Is phytoplankton growth in the Wadden Sea light or nitrogen limited? Journal of Sea Research 49: 83-93.

Cooper, S., and G. Brush. 1991. Long term history of Chesapeake Bay anoxia. Science 254: 992-996.

EPD (Environmental Protection Department). 2004. Marine water quality in Hong Kong in 2004. Hong Kong: Hong Kong Government Printer. Website: http://www.epd.gov.hk/epd/english/ environmentinhk/water/river_quality/rwq report.html.

EPD (Environmental Protection Department). 2006. Marine water quality in Hong Kong in 2006. Hong Kong: Hong Kong Government Printer. Website: http://www.epd.gov.hk/epd/english/ environmentinhk/water/river_quality/rwq_report.html.

Fisher, T.R., A.B. Gustafson, K. Sellner, R. Lacouture, L.W. Haas, R. L. Wetzel, R. Magnien, D. Everitt, B. Michaels, and R. Karrh. 1999. Spatial and temporal variation of resource limitation in Chesapeake Bay. Marine Biology 133: 763-778.

Fisher, T.R., J.D. Hagy III, W.R. Boynton, and M.R. Williams. 2006. Cultural eutrophication in the Choptank and Patuxent estuaries of Chesapeake Bay. Limnology and Oceanography 51: 435-447.

Gowen, R.J., D.J. Hydes, D.K. Mills, B.M. Stewart, J. Brown, C.E. Gibson, T.M. Shammon, M. Allen, and S.J. Malcolm. 2002. Assessing trends in nutrient concentrations in coastal shelf seas: A case study in the Irish Sea. Estuarine, Coastal and Shelf Science 54: 927-939.

Heip, C., N. Goosen, P.M.J. Herman, J. Kromkamp, J. Middelburg, and K. Soetaert. 1995. Production and consumption of biological particles in temperate tidal estuaries. Oceanography and Marine Biology Annual Review 33: 1-49.

Ho, A.Y.T. 2007. Dynamics of nutrients and phytoplankton biomass and production in Hong Kong waters. Ph.D. thesis. The Hong Kong University of Science and Technology.

Howarth, R.W., D.P. Swaney, T.J. Bulter, and R. Marino. 2000. Climatic control on eutrophication of the Hudson River estuary. Ecosystems 3: 210-215.

Jeffrey, S.W., and G.F. Humphrey. 1975. New spectrophotometric equations for determining chlorophyll a, b, and c, in higher plants, algae and natural phytoplankton. Biochemie and Physiologie der Pflantzen 167: 191-194.

Justić, D., N.N. Rabalais, R.E. Turner, and Q. Dortch. 1995. Changes in nutrient structure of river-dominated coastal watersstoichiometric nutrient balance and its consequences. Estuarine, Coastal and Shelf Science 40: 339-356.

Justić, D., N.N. Rabalais, and R.E. Turner. 1997. Impacts of climate change on net productivity of coastal waters: Implications for carbon budgets and hypoxia. Climate Research 8: 225-237.

Le Pape, O., Y. Del Amo, A. Ménesguen, B. Quequiner, and P. Treguer. 1996. Resistance of a coastal ecosystem to increasing eutrophic conditions: The Bay of Brest (France), a semi-enclosed zone of Western Europe. Continental Shelf Research 16: 1885-1907.

Lee, J.H.W., and A.G. Qian. 2003. Three-dimensional modeling of hydrodynamic and flushing in deep bay. Proceeding of International Conference on Estuaries and Coasts, Nov. 9-11, 2003. Zhejiang University Press, pp. 814-821 
Malakoff, D. 1998. Death by suffocation in the Gulf of Mexico. Science 281: 1901-1992.

Natarajan, K.V. 1970. Toxicity of ammonium to marine diatoms. Journal Water Pollution Control Federation 42: 184-190.

Nedwell, D.B., L.F. Dong, A. Sage, and G.J.C. Underwood. 2002. Variations of the nutrients loads to the mainland U.K. Estuaries: Correlation with catchment areas, urbanization and coastal eutrophication. Estuarine Coastal and Shelf Science 54: 951-970.

Nixon, S.W. 1995. Coastal marine eutrophication: A definition, social cause, and future concerns. Ophelia 41: 199-219.

O'Shea, M.L., and T.M. Brosnan. 2000. Trends in indicators of eutrophication in western Long Island Sound and the HudsonRaritan Estuary. Estuaries 23: 877-901.

Paerl, H.W., L.M. Valdes, M.F. Piehler, and C.A. Stow. 2006. Assessing the effects of nutrient management in an estuary experiencing climatic change: The Neuse River estuary, North Carolina. Environmental Management 37: 422-436.

Philippart, C.J.M., G.C. Cadee, W. Van Raaphorst, and R. Riegman. 2000. Long term phytoplankton-nutrient interactions in a shallow coastal sea: Algal community structure, nutrient budgets and denitrification potential. Limnology and Oceanography 45: $131-144$

Pinckney, J.L., H.W. Paerl, and M.B. Harrington. 1999. Responses of the phytoplankton community growth rate of nutrient pulses in variable estuarine environments. Journal of Phycology 35: 1455-1463.

Ragueneau, O., C. Lancelot, V. Egorov, J. Vervlimmeren, A. Cociasu, G. Déliat, A. Krastev, N. Daoud, V. Rousseau, V. Popovitchev, N. Brion, L. Popa, and G. Cauwet. 2002. Biogeochemical transformations of inorganic nutrients in the mixing zone between the Danube River and the North-western Black Sea. Estuarine, Coastal and Shelf Science 54: 321-336.

Rosenberg, R. 1985. Eutrophication-The future marine coastal nuisance? Marine Pollution Bulletin 16: 227-231.

Ryther, J.H., and W.M. Dunstan. 1971. Nitrogen, phosphorus, and eutrophication in the coastal marine environment. Science 171: $1008-1013$.

Sanders, R.J., T. Jickell, S. Malcolm, J. Brown, D. Kirkwood, A. Reeve, J. Taylor, T. Horrobin, and C. Ashcroft. 1997. Nutrient fluxes through the Humber Estuary. Journal of Sea Research 37: 3-23.

Soetaert, K., P.M.J. Herman, and J. Kromkamp. 1994. Living in the twilight-estimating net phytoplankton growth in the Westerschelde estuary (The Netherlands) by means of an ecosystem model (MOSES). Journal of Plankton Research 16: 1277-1301.

Soetaert, K., J.J. Middelburg, C. Heip, P. Meire, A. Van Damme, and T. Maris. 2006. Long term change in dissolved inorganic nutrients in the heterotrophic Scheldt estuary (Belgium, The Netherlands). Limnology and Oceanography 51: 409-423.
St. John, J. 1990. Nutrient/organic input and fate in the harbor-soundBight system. In Proceedings of Cleaning up our coastal waters: An unfinished agenda, ed. K. Swelow and M.T. Southerland, 203-221. Riverdale: Manhattan College.

Thomas, W.H., J. Hastings, and M. Fujita. 1980. Ammonium inputs to the sea via large sewage outfalls part 2: Effects of ammonium on growth and photosynthesis of southern California phytoplankton cultures. Marine Environmental Research 3: 291-296.

Truesdal, G.A., A.L. Downing, and G.F. Lowden. 1955. The solubility of oxygen in pure water and sea-water. Journal of Applied Chemistry 5: 53-62.

Watts, J.C.D. 1983. Further observations on the hydrology of the Hong Kong territorial waters. Hong Kong Fisheries Bulletin 3: 9-35.

Wong, K.T.M., J.H.W. Lee, and P.J. Harrison. 2009. Forecasting of environmental risk maps of coastal algal blooms. Harmful Algae 8: $407-420$.

Xu, J., A.Y.T. Ho, K. Yin, X. Yuan, D.M. Anderson, J.H.W. Lee AND, and P.J. Harrison. 2008. Temporal and spatial variations in nutrient stoichiometry and regulation of phytoplankton biomass in Hong Kong waters: Influence of the Pearl River outflow and sewage inputs. Marine Pollution Bulletin 57: 335-348.

Xu, J., K. Yin, A.Y.T. Ho, J.H.W. Lee, D.M. Anderson, and P.J. Harrison. 2009. Regulation of nutrient limitation in Hong Kong waters inferred from comparison of nutrient ratios, nutrient enrichment bioassays, and ${ }^{33} \mathrm{P}$ turnover times. Marine Progress Ecology Series.. doi:10.3354/meps08098.

Yin, K. 2002. Monsoonal influence seasonal variations in nutrients and phytoplankton biomass in the coastal waters of Hong Kong in the vicinity of the Pearl River estuary. Marine Progress Ecology Series 245: 111-122.

Yin, K., P.J. Harrison, J.C. Chen, W. Huang, and P.Y. Qian. 1999. Red tides during spring 1998 in Hong Kong waters: Is El Niño responsible? Marine Progress Ecology Series 187: 289-294.

Yin, K., P.Y. Qian, J.C. Chen, D.P.H. Hsieh, and P.J. Harrison. 2000. Dynamics of nutrients and phytoplankton biomass in the Pearl River estuary and adjacent waters of Hong Kong during summer: Preliminary evidence for phosphorus and silicon limitation. Marine Progress Ecology Series 194: 295-305.

Yin, K., P.Y. Qian, M.C.S. Wu, J.C. Chen, L.M. Huang, X.Y. Song, and W.J. Jian. 2001. Shift from P to N limitation of phytoplankton biomass across the Pearl River estuarine plume during summer. Marine Progress Ecology Series 221: 17-28.

Yoshiyama, K., and J.H. Sharp. 2006. Phytoplankton response to nutrient enrichment in an urbanized estuary: Apparent inhibition of primary production by overeutrophication. Limnology and Oceanography 51: 424-434. 